\title{
Szpitale diecezji żmudzkiej na początku XIX stulecia
}

Słowa kluczowe: bp Józef Arnulf Giedroyć, diecezja żmudzka, parafia, szpital, Żmudź

Dzieje szpitalnictwa polskiego do końca XVIII w. mogą poszczycić się dość bogatą literaturą. Wystarczy wymienić najważniejsze prace, aby przekonać się, że większość epoki przedrozbiorowej ma starsze bądź nowsze badania opisujące to zagadnienie na ich obszarze ${ }^{1}$. Niestety, wśród nich próżno szukać diecezji żmudzkiej. Szpitale - szczycącego się średniowiecznym rodowodem - biskupstwa do tej pory nie doczekały się opracowania zarówno dla epoki staropolskiej, jak i okresu późniejszego. Wyjątek stanowi tutaj artykuł autorstwa prof. Vaidy Kamuntavičienè poświęcony szkołom $\mathrm{i}$ szpitalom $\mathrm{w}$ dwóch diecezjach litewskich w II poł. XVII w. ${ }^{2}$ oraz rozprawa w języku litewskim prof. Aldony Prašmantaitė o bp. Józefie Arnulfie Giedroyciu. W jednym z podrozdziałów tej pracy omówiono zagadnienie przytułków parafialnych $\mathrm{w}$ diecezji podczas rządów wspomnianego biskupa ${ }^{3}$. $\mathrm{Z}$ powodu braku badań stan szpitali na Żmudzi nie został zobrazowany przez

${ }^{1}$ Stan badań dotyczący szpitalnictwa i opieki społecznej w Polsce do końca XVIII w. został szczegółowo omówiony w fundamentalnych dla zagadnienia pracach S. Litaka pt. Parafie Rzeczypospolitej w XVI-XVIII wieku, Lublin 2004 oraz M. Surdackiego pt. Opieka społeczna w Polsce do końca XVIII wieku, Lublin 2015.

${ }^{2}$ Szpitale $i$ szkoły parafialne diecezji wileńskiej $i$ żmudzkiej $w$ drugiej połowie XVII wieku wedtug danych akt wizytacyjnych Kościoła katolickiego, „Kwartalnik Historyczny" 2003, R. 110, nr 2, s. 51-72.

3 A. Prašmantaitè, Žemaičiu vyskupas Juozapas Arnulfas Giedraitis, Vilnius 2000. 


\section{Summary}

\section{Hospitals of the diocese of Żmudź at the beginning of the XIXth century}

The aim of this article is to present a problem of social welfare in the diocese of Żmudź at the beginning of the XIXth century. In the article a source - as a fundamental material needed to write this publication, the condition of the diocese of Żmudź on the turn of the XVIIIth and XIXth centuries, the condition of hospital management on Polish and Lithuanian lands on the turn of the centuries will be presented. In the article a system of hospitals of the diocese of Żmudź, allowance and funds of hospitals, hospital buildings, and finally the poor without which the hospitals would not have existed will also be presented. By Żmudź hospitals we understand all hospital shelters which worked at parish, branch - and monastic churches at that time. The appendix which presents a system of parish hospitals in the diocese of Żmudź based on dean inspections coming from 1805-1806 is a supplement to the whole article. 
funduszowych i stąd wynikającej intracie, czyli dochodach, jako też o nieuchronnych wydatkach, na końcu o obligacjach duchownych, o liczbie parafian i szczególnościach metrycznych"6. W tabele takie zaopatrzone są raporty dziekańskie przesłane za $1806 \mathrm{r}$. Nie mają ich natomiast raporty dostarczone za $1805 \mathrm{r}$.

W aktach wizytacyjnych obok ważnych zapisów dotyczących kościoła parafialnego (wygląd wewnętrzny i zewnętrzny, wyposażenie, budynki, uposażenie, duchowieństwo) znajdują się także informacje na temat istnienia bądź braku przy parafii szpitala dla ubogich. Zazwyczaj są to krótkie notatki, na podstawie których możemy ustalić: fundatora, usytuowanie szpitala, wygląd i stan zachowania budynków, warunki bytowe, uposażenie i liczbę pensjonariuszy. Dokładniejszych danych dostarczają opisy szpitali publicznych i prowadzonych przez zakonników. $\mathrm{W}$ ich przypadku obok zwyczajnych danych wymieniano personel zatrudniony w szpitalu wraz z podaniem wieku i lat od wstąpienia do klasztoru oraz listę imienną ubogich, także z wyszczególnieniem wieku oraz liczby lat przebywania w przytułku?

Takie właśnie sprawozdania przygotowane za czasów biskupa żmudzkiego J.A. Giedroycia z 1805 r. i 1806 r., jak zaznaczono we wstępie, stały się podstawą badań dla niniejszego opracowania. Dokumenty te, stanowiące dzisiaj bezcenne źródło informacji, przechowywane są w Litewskim Państwowym Archiwum Historycznym w Wilnie (Lietuvos Centrinis Valstybès Archyvas). Tworzą poszyt oznaczony sygnaturą f. 669, ap. 2, b. 221. Według oficjalnej foliacji całość woluminu liczy 668 kart. W rzeczywistości jest ich mniej, bo 568. Prawdopodobnie $\mathrm{w}$ czasie numerowania kolejnych kart doszło do pomyłki, w efekcie której po karcie numer 120 następuje karta numer $220^{8}$.

\section{Diecezja żmudzka na przełomie XVIII i XIX w.}

Diecezja żmudzka przed rozbiorami wchodziła w skład metropolii gnieźnieńskiej. Obejmowała tereny Księstwa Żmudzkiego i województwa trockiego o powierzchni $25150 \mathrm{~km}^{2}$. Sąsiadowała z diecezjami: inflancką (od północy), warmińską (od zachodu i południowego zachodu), wileńską (od południa i wschodu). Jej struktury duszpasterskie tworzyło 99 kościołów parafialnych, 118 kościołów filialnych i kilkadziesiąt kaplic, zorganizowanych w 10 dekanatach: 1) Janiszki, 2) Kroki,

\footnotetext{
${ }^{6}$ Tamże, k. 317.

7 Zob. np.: tamże, k. 646

${ }^{8}$ Zobacz informacje zamieszczone na wklejce na końcu księgi, LIVA, f. 669, ap. 2, b. 221. 
3) Olsiady, 4) Retów, 5) Szadów, 6) Szkudy, 7) Szydłów, 8) Wieksznie, 9) Wielona, 10) Wornie 9 .

Trzeci rozbiór Polski podzielił diecezję pomiędzy Rosję i Prusy. Po stronie rosyjskiej została większa część jej terytorium ze stolicą w Worniach. Natomiast niewielki wycinek obejmujący 15 parafii położonych na lewym brzegu Niemna w rejonie Kowna znalazł się w zaborze pruskim. Już wówczas było wiadomo, że zgodnie z polityką zaborców mającą na celu dostosowanie granic diecezji do podziału administracji państwowej parafie te zostaną odłączone od macierzystego biskupstwa. Początkowo rząd pruski zamierzał włączyć je do diecezji warmińskiej. Odstąpiono jednak od tych planów. 8 stycznia 1797 r. jurysdykcję kościelną nad pruską częścią diecezji żmudzkiej przejął bp płocki Krzysztof Hilary Szembek. Wkrótce - 21 lutego 1797 r. administratorem omawianego terytorium, na mocy nominacji ordynariusza płockiego, został ks. Michał Franciszek Karpowicz, archidiakon smoleński. Po erygowaniu w 1799 r. diecezji wigierskiej 15 żmudzkich parafii włączono do nowego biskupstwa ${ }^{10}$.

Zmiany terytorialne, które nastąpiły w wyniku reorganizacji struktur kościelnych na tzw. ziemiach zabranych, przeprowadzone w $1798 \mathrm{r}$. przez delegata apostolskiego Wawrzyńca Littę, nie objęły bezpośrednio diecezji żmudzkiej. Zachowała ona swoje przedrozbiorowe granice, z wyjątkiem wcześniejszej utraty parafii na rzecz diecezji wigierskiej (ok. 10\% terytorium). Zmieniła się natomiast jej przynależność metropolitalna. W efekcie podjętych ustaleń diecezja żmudzka wraz $\mathrm{z}$ diecezją wileńską została wyłączona z gnieźnieńskiej prowincji kościelnej i przyłączona do powstałej wówczas metropolii mohylewskiej. Metropolia ze stolicą w Mohylewie obejmowała siedem jednostek kościelnych $\mathrm{w}$ cesarstwie rosyjskim: archidiecezje mohylewską oraz diecezje: wileńską, żmudzką, łucką i żytomierską (połączone unią personalną), kamieniecką i mińską ${ }^{11}$.

Po rozbiorach diecezja żmudzka pod względem administracji państwowej rozciągała się na części guberni wileńskiej i niewielkim skrawku guberni kurlandzkiej. W granicach drugiej z wymienionych guberni

${ }^{9}$ G. Błaszczyk, Diecezja żmudzka od XV do początku XVII wieku, Poznań 1993, s. 22-28; S. Litak, Atlas Kościoła łacińskiego w Rzeczypospolitej Obojga Narodów $w$ XVIII wieku, Lublin 2006, s. 92.

${ }^{10}$ S. Czerski, Opis Żmudzkiey Dyecezyi, Wilno 1850, s. 7; B. Kumor, Granice metropolii i diecezji polskich (968-1939), „ABMK” 1970, t. 20, s. 303.

11 J. Skarbek, Kościót rzymskokatolicki na Białorusi i Litwie w XIX $i$ na początkach XX stulecia, „Sympozjum” 1999, R. 3, nr 1(4), s. 15-16. 
leżała jedynie parafia Połąga, należąca do dekanatu Szkudy ${ }^{12}$. Od $1778 \mathrm{r}$. na tronie biskupim w Worniach zasiadał Jan Stefan Giedroyć. W 1801 r. z powodu choroby przekazał on rządy w diecezji na ręce swojego krewnego J.A. Giedroycia, dotychczasowego koadiutora cum futura successione $^{13}$. Nowy ordynariusz już na początku swoich rządów dokonał niewielkich korekt w organizacji wewnątrzdiecezjalnej. Powstał wówczas dekanat Botoki, wydzielony z trzech dekanatów: Wornie (9 parafii i 3 filie) $)^{14}$ oraz dekanatów Retów (1 filia) i Szydłów (1 filia) ${ }^{15}$.

Po tych korektach diecezja dzieliła się na 11 dekanatów (dotąd 10): 1) Botoki, 2) Janiszki, 3) Kroki, 4) Olsiady, 5) Retów, 6) Szadów, 7) Szkudy, 8) Szydłów, 9) Wieksznie, 10) Wielona, 11) Wornie. Liczyła 108 parafii i 56 filii. Na jej terenie działalność prowadziło 14 męskich klasztorów i 2 żeńskie ${ }^{16}$. W takiej strukturze administracyjnej diecezja przetrwała do połowy XIX stulecia. Dalsze zmiany granic nadeszły w następstwie negocjacji i podpisania konkordatu z 3 sierpnia $1847 \mathrm{r}$. oraz bulli papieża Piusa IX Universalis Ecclesiae cura podpisanej tego samego dnia ${ }^{17}$.

Tab. 1. Dekanaty diecezji żmudzkiej na początku XIX stulecia

\begin{tabular}{|c|l|c|c|l|c|}
\hline Lp. & Nazwa dekanatu & $\begin{array}{c}\text { Liczba } \\
\text { parafii }\end{array}$ & Lp. & $\begin{array}{c}\text { Nazwa } \\
\text { dekanatu }\end{array}$ & $\begin{array}{c}\text { Liczba } \\
\text { parafii }\end{array}$ \\
\hline $\mathbf{1 .}$ & Botoki & 12 & $\mathbf{7 .}$ & Szkudy & 7 \\
\hline $\mathbf{2 .}$ & Janiszki & 12 & $\mathbf{8 .}$ & Szydłów & 8 \\
\hline $\mathbf{3 .}$ & Kroki & $\mathbf{9}$ & $\mathbf{9 .}$ & Wielona & 11 \\
\hline $\mathbf{4 .}$ & Olsiady & 10 & $\mathbf{1 0 .}$ & Wieksznie & 9 \\
\hline $\mathbf{5 .}$ & Retów & 12 & $\mathbf{1 1 .}$ & Wornie & 8 \\
\hline $\mathbf{6 .}$ & Szadów & 10 & & & \\
\hline
\end{tabular}

Źródło: LIVA, f. 669, ap. 2, b. 221, k. 1-120, 220-651.

12 A. Prašmantaitè, Żmudzki biskup Józef Arnulf Giedroyć (1757-1838) i jego diecezja, Poznań 2001, s. 9-10.

${ }_{13}$ M. Godlewski, Giedroyć Józef Arnolf, [w:] Polski Słownik Biograficzny, t. 7, Kraków 1948-1958, s. 428.

${ }^{14} \mathrm{Z}$ tego też powodu dekanat z siedzibą w Botokach w źródłach nazywany jest także dekanatem Wornie II. LIVA, f. 669, ap. 2, b. 221, k. 492.

${ }^{15} \mathrm{Z}$ dekanatu wornieńskiego były to parafie: Gawra, Taurogi, Szyłele, Niemokszty, Kołtyniany, Poszyle, Skaudwile, Botoki oraz filie Korklany, Bolsie, Upina; z dekanatu retowskiego filia Pogromoncie; $z$ dekanatu szydłowskiego filia Poszołtuń. Dla trzech przyłączonych do nowego dekanatu parafii (Girdyszki, Odachów, Stulgia) nie udało się ustalić przedrozbiorowej przynależności dekanalnej.

${ }^{16}$ Wszystkie obliczenia na podstawie raportów dziekańskich z lat 1805-1806. LIVA, f. 669 , ap. 2, b. 221, k. 261-651.

17 B. Kumor, Ustrój i organizacja Kościoła polskiego w okresie niewoli narodowej (1772-1918), Kraków 1980, s. 197. 
Marek Hałaburda

\section{Szpitalnictwo na ziemiach polskich na przełomie XVIII i XIX stulecia}

Przenikające do Rzeczypospolitej z Europy Zachodniej idee oświeceniowe przyniosły zupełnie nowe podejście do problemu opieki społecznej oraz zdrowia obywateli. Dotychczasowa idea religijna chrześcijańskiego miłosierdzia miała zostać zastąpiona ideą filantropijną. O ile do tej pory jedynym organizatorem dobroczynności był Kościół, o tyle od chwili objęcia tronu przez Stanisława Augusta Poniatowskiego zainicjowano próby zsekularyzowania, zreformowania i poddania szpitali kontroli państwowej ${ }^{18}$. W 1775 r. polski sejm uchwalił ustawę dotyczącą szpitali. Powoływała ona do życia dwie specjalne Komisje Szpitalne - Koronną i Litewską. W Komisji Koronnej zasiadał prymas, 9 biskupów, 4 wojewodów, 2 kasztelanów oraz 21 przedstawicieli szlachty. W skład Komisji Litewskiej wchodziło 4 biskupów, 3 senatorów i 15 osób ze stanu szlacheckiego. Ponadto w Komisji Koronnej zasiadało 36 komisarzy, w litewskiej - 22. Posiedzenia pierwszej z wymienionych komisji miały się odbywać w Warszawie, drugiej w Wilnie. Komisja została upoważniona do przeprowadzenia lustracji szpitali. W pierwszym rzędzie chodziło o spisanie funduszy, gruntów, przywilejów szpitali i budynków szpitalnych oraz wyeliminowanie nadużyć i likwidację niepotrzebnych pojedynczych placówek. Pieniądze pozyskane w wyniku uporządkowania finansów, a także ze sprzedaży zbędnych budynków zamierzano przeznaczyć na budowę w każdym województwie jednego szpitala generalnego. Ubodzy ze szpitali parafialnych mieli być przeniesieni do szpitali ,wielkich”. W przytułkach parafialnych planowano pozostawić tylko osoby niezbędne do posługi przy kościele. Zniszczone szpitale miały zostać rozebrane, a na ich miejscu planowano urządzić cmentarze. Zamierzano także przeznaczać na szpitale kolegia pojezuickie, niezajęte dotychczas na cele edukacyjne ${ }^{19}$.

Nadrzędnym celem prac komisji było całkowite wyeliminowanie żebractwa. Wszystkie osoby niepotrafiące zarobić na swoje utrzymanie należało umieścić $\mathrm{w}$ szpitalach. Tam planowano dokonywać selekcji, w wyniku której ludzi zdrowych i w sile wieku kierowano by na przymusowe roboty publiczne. Według planów darmowy pobyt $\mathrm{w}$ szpitalu oraz leczenie i żywność gwarantowano wszystkim

\footnotetext{
${ }^{18}$ M. Dola, Opieka społeczna Kościoła, [w:] B. Kumor, Z. Obertyński (red.), Historia Kościoła w Polsce, t. 2, cz. 1, Poznań-Warszawa 1979, s. 343.

${ }^{19}$ Rys historyczno-statystyczny szpitali i innych zakładów dobroczynnych w Królestwie Polskim, t. 1, Warszawa 1872, s. 160-164.
} 
chorującym, o ile posiadaliby świadectwo ubóstwa wystawione przez proboszcza i magistrat lub mogli przedstawić dwóch wiarygodnych świadków. Dopuszczano możliwość przyjmowania do szpitali zamożniejszych pacjentów, ale tylko wtedy, kiedy w momencie przybycia do placówki uiściliby oni uzgodnione wcześniej wpisowe. W każdym szpitalu miał być doktor i felczer zobowiązany do pomocy przy porodach oraz szkoła przygotowawcza dla położnych na potrzeby prowincjonalnych miast i wsi ${ }^{20}$. W rzeczywistości działalność Komisji Koronnej ograniczyła się do czterech zebrań odbytych w latach 17751776. Prawdopodobnie w taki sam sposób przebiegały prace Komisji Litewskiej. Niespokojne czasy rozbiorów oraz brak władzy wykonawczej sprawił, że ostatecznie reform nie udało się wprowadzić w całości. Komisje szpitalne upadły już w 1780 r. Chociaż żywot komisji był krótkotrwały, to odegrały one istotną rolę na drodze do zmiany funkcji szpitali z przytułku dla ubogich na funkcje leczniczą. Nadzór nad szpitalnictwem i sprawami sanitarnymi w 1789 r. przejęły Komisje Porządkowe Cywilno-Wojskowe, a w 1791 r. Komisje Policji Obojga Narodów ${ }^{21}$. Upadek Rzeczypospolitej przerwał reformy prowadzące do utworzenia nowoczesnego szpitalnictwa, którego główną funkcją miało pozostawać leczenie. Po kongresie wiedeńskim nowe porządki zaprowadzały już mocarstwa zaborcze, przenosząc obowiązek opieki nad ubogimi z władzy kościelnej (parafie) na władze lokalne świeckie (magistraty i gminy) ${ }^{22}$.

\section{Sieć szpitali}

Gdy weźmie się pod uwagę brak przekrojowych badań nad szpitalnictwem w diecezji żmudzkiej, zarówno dla okresu staropolskiego, jak i czasów porozbiorowych, niesłychanie istotne wydaje się ustalenie sieci szpitali parafialnych na początku interesującego nas stulecia. Umożliwia to analiza raportów dziekańskich, przekazujących informacje o wszystkich działających szpitalach na terenie zwizytowanych parafii. Zjawisko to ilustruje poniższe zestawienie.

Jak wynika z zestawienia, w diecezji żmudzkiej na początku XIX w. prawie $92 \%$ parafii posiadało szpitale. Do otrzymanej liczby należy dodać przytułki przy filiach Połany i Upina w dekanacie Botoki, które

\footnotetext{
${ }^{20}$ Tamże, s. 164-165.

${ }^{21}$ Z. Podgórska-Klawe, Od hospicjum do wspótczesnego szpitala. Rozwój historyczny problematyki szpitalnej w Polsce do końca XIX wieku, Wrocław-Warszawa-Kraków 1981, s. 53-55.

${ }^{22}$ K. Dola, Opieka społeczna Kościoła, [w:] B. Kumor, Z. Obertyński (red.), Historia Kościoła w Polsce, t. 2, cz. 1, Poznań-Warszawa 1979, s. 699.
} 
Tab. 2. Sieć szpitali w diecezji żmudzkiej według raportów dziekańskich w latach 1805-1806

\begin{tabular}{|c|c|c|c|c|c|c|c|c|c|}
\hline \multirow{3}{*}{ Lp. } & \multirow{3}{*}{ Dekanat } & \multirow{3}{*}{$\begin{array}{l}\text { Liczba } \\
\text { parafii }\end{array}$} & \multirow{3}{*}{$\begin{array}{c}\text { Liczba } \\
\text { filii }\end{array}$} & \multirow{3}{*}{$\begin{array}{l}\text { Kościoły } \\
\text { zakonne }\end{array}$} & \multicolumn{5}{|c|}{ Dane o szpitalach } \\
\hline & & & & & \multicolumn{2}{|c|}{ szpitale } & \multicolumn{2}{|c|}{$\begin{array}{c}\text { brak } \\
\text { szpitali }\end{array}$} & \multirow[t]{2}{*}{ razem } \\
\hline & & & & & $\mathbf{p}$ & $\mathbf{f}$ & $\mathbf{p}$ & $\mathbf{f}$ & \\
\hline 1. & $\begin{array}{l}\text { Botoki } \\
\text { (Wornie II) }\end{array}$ & 12 & 5 & & 8 & 2 & 3 & 4 & 17 \\
\hline 2. & Janiszki & 12 & 6 & & 10 & $3 *$ & 2 & 4 & 19 \\
\hline 3. & Kroki & 8 & 6 & & 7 & 5 & 1 & 1 & 14 \\
\hline 4. & Olsiady & 10 & 15 & & 9 & 2 & 1 & 13 & 25 \\
\hline 5. & Retów & 12 & 7 & & 12 & - & - & 7 & 19 \\
\hline 6. & Szadów & 10 & 2 & & 10 & - & - & 2 & 12 \\
\hline 7. & Szkudy & 8 & 7 & & $8^{* *}$ & 2 & 1 & 5 & 16 \\
\hline 8. & Szydłów & 8 & 3 & & 8 & 2 & - & 1 & 11 \\
\hline 9. & Wieksznie & 9 & 2 & & 9 & 2 & - & - & 11 \\
\hline 10. & Wielona & 11 & 1 & 2 & 11 & - & - & 1 & 12 \\
\hline \multirow[t]{2}{*}{11.} & Wornie & $9 * * *$ & 2 & - & 8 & 1 & 1 & 1 & 11 \\
\hline & Razem & 109 & 56 & & 100 & 19 & 9 & 38 & 167 \\
\hline
\end{tabular}

\section{Objaśnienia:}

$\mathrm{p}$ - parafia

f - filia

* W parafii Gruździe były dwa oddzielne szpitale dla kobiet i mężczyzn.

** W parafii Sałanty istniały dwa oddzielne szpitale dla kobiet i mężczyzn.

*** Do parafii dekanatu Wornie włączono kościół katedralny formalnie nietworzący odrębnej parafii.

Źródło: LIVA, f. 669, ap. 2, b. 221, k. 1-120, 220-651.

uzupełniały brak szpitali przy macierzystej parafii w Bejsagołach i Girdyszkach. Co ważne, obok kościołów parafialnych przytułki dla ubogich działały także dość często przy świątyniach pomocniczych. Spośród 56 istniejących wówczas filii przytułki - oprócz dwóch wymienionych wyżej - były zorganizowane jeszcze przy 19 (33,93\%). W dwóch przypadkach - przy kościele filialnym w Gruździach oraz przy kościele parafialnym w Sałantach - ubodzy korzystali z oddzielnych budynków dla mężczyzn i kobiet ${ }^{23}$.

Sytuacja pod względem sieci szpitali najlepiej przedstawiała się w dekanatach Retów, Szadów, Szydłów, Wieksznie i Wielona. Tam wszystkie parafie posiadały szpitale. Dodatkowo na terenie dekanatów

\footnotetext{
${ }^{23}$ LIVA, f. 669, ap. 2, b. 221, k. 386-386v, 425v.
} 
Szkudy, Szydłów i Wieksznie działały po dwa szpitale przy kościołach filialnych. Natomiast żadna z filii dekanatu retowskiego, szydłowskiego i wielońskiego ich nie miała.

Miejsca, w których szpitale nie funkcjonowały, to miasta: Bejsagoła (dek. Kroki), Kruki i Nowe Żagory (dek. Janiszki), Łukniki (dek. Wornie), Pogromoncie (dekanat Botoki) i wsie: Drobiany (dek. Szkudy), Girdyszki i Taurogi (dek. Botoki), Pikiele (dek. Olsiady). Jednocześnie należy podkreślić, że w dwóch $\mathrm{z}$ wymienionych miast - Nowe Żagory (dek. Janiszki) i Pogromoncie (dek. Botoki) - wizytator odnotował trwanie prac przy wznoszeniu nowego budynku szpitalnego ${ }^{24}$.

Jeśli weźmiemy pod uwagę obszar, jaki zajmowała diecezja żmudzka w interesującym nas okresie, łatwo obliczyć, że jeden szpital przypadał przeciętnie na $211,3 \mathrm{~km}^{2}$. Zróżnicowanie pod tym względem w dekanatach oscylowało między $159,4 \mathrm{~km}^{2} \mathrm{w}$ dekanacie Szkudy do $256 \mathrm{~km}^{2} \mathrm{w}$ dekanacie Janiszki.

Nasuwa się pytanie, jak sieć szpitali parafialnych diecezji żmudzkiej przedstawiała się $\mathrm{w}$ porównaniu $\mathrm{z}$ innymi diecezjami wschodnimi. Z powodu niedostatku szczegółowych badań dla XIX w. zmuszeni jesteśmy odwołać się do okresu przedrozbiorowego. Zastrzegając jednak, że pewne procesy na Żmudzi zachodziły później, można te dane uznać z dużym prawdopodobieństwem za miarodajne. I tak, w sąsiedniej diecezji wileńskiej według statystki z 1781 r. odsetek parafii ze szpitalami sięgał $71 \%$. Jeden szpital $\mathrm{w}$ tej diecezji przypadał na $744 \mathrm{~km}^{2}$, przy jednoczesnym dużym zróżnicowaniu dekanalnym od $163 \mathrm{~km}^{2}$ (dek. Olita) do $11664 \mathrm{~km}^{2}$ (dek. Bobrujsk) ${ }^{25}$. Wysoki odsetek parafii ze szpitalem zdają się potwierdzać również badania przeprowadzone nad czterema dekanatami tej diecezji: Brasław, Kowno, Pobojsk i Wiłkomierz z lat 1782-1784, które wykazały, że około 78,7\% parafii $\mathrm{w}$ tym czasie posiadało szpital. Na przebadanym terenie, obejmującym obszar $20230 \mathrm{~km}^{2}$, jeden szpital przypadał średnio na $326,3 \mathrm{~km}^{2}{ }^{26}$. W archidiecezji lwowskiej w połowie XVIII w. szpitale funkcjonowały w 42 ze 106 wszystkich parafii (40\%), a jeden szpital przypadał na $695 \mathrm{~km}^{27}$. Podobnie w diecezji kamienieckiej w połowie

\footnotetext{
${ }^{24}$ Tamże, k. 414v-415, 496v.

${ }^{25} \mathrm{~J}$. Kurczewski, Biskupstwo wileńskie od jego założenia aż do dni obecnych, zawierajace dzieje i prace biskupów i duchowieństwa diecezji wileńskiej oraz wykaz kościotów, klasztorów, szkót i zakładów dobroczynnych i społecznych, Wilno 1912, s. 376.

${ }^{26}$ W. Partyka, Szpitale $w$ diecezji wileńskiej w drugiej połowie XVIII wieku, [w:] M. Surdacki (red.), Religia - Edukacja - Kultura, , Lublin 2002, s. 625.

${ }^{27} \mathrm{~J}$. Krętosz, Organizacja archidiecezji lwowskiej obrzadku tacińskiego od XV wieku do 1772 roku, Lublin 1986, s. 265.
} 
XVIII w. 36,5\% parafii posiadało szpital. Jeden szpital przypadał tam na prawie $915 \mathrm{~km}^{2}$. Na jeszcze niższym poziomie kształtowała się sieć szpitali w diecezji łuckiej. Tam w połowie XVIII w. istniało 50 szpitali w 260 parafiach (22\%), a jeden szpital przypadał na $617 \mathrm{~km}^{2}$. Z tym że znakomita ich większość występowała w archidiakonacie brzeskolitewskim, a w archidiakonacie łuckim było ich zaledwie kilka ${ }^{28}$. Jak widać, diecezja żmudzka na polu szpitalnictwa przodowała nad wschodnimi diecezjami Rzeczypospolitej, położonymi na ziemiach ruskich i litewskich. W zestawieniu liczby szpitali z liczbą parafii wyprzedzała nawet lepiej zorganizowane i bogatsze diecezje staropolskie. W diecezji krakowskiej w połowie XVIII w. funkcjonowało 526 szpitali na 890 parafii $(59,10 \%)$, w diecezji połockiej w 1781 r. - ok. 98 szpitali na 153 parafie (64\%), poznańskiej w latach 1777-1784 - ok. 191 szpitali na 466 parafii (41\%), w diecezji włocławskiej w 1772 r. - ok. 92 szpitale na 203 parafie (35\%), warmińskiej w drugiej połowie XVIII w. - 30 (w 20 parafiach) na 77 wszystkich parafii $(25,97 \%$ ), gnieźnieńskiej w latach 1766-1767 - ok. 169 szpitali na 676 parafii (25\%). Natomiast ustępowała im jednak zdecydowanie pod względem gęstości sieci szpitalnej. W diecezji krakowskiej jeden szpital przypadał na ok. $101 \mathrm{~km}^{2}$; płockiej na ok. $126 \mathrm{~km}^{2}$; poznańskiej na ok. $118 \mathrm{~km}^{2}$; warmińskiej - $152 \mathrm{~km}^{2}$; gnieźnieńskiej - $186 \mathrm{~km}^{2}$. Korzystniej wypadała jedynie na tle diecezji włocławskiej, w której jeden szpital w 1772 r. przypadał na ok. $259 \mathrm{~km}^{2} 29$.

\section{Fundatorzy szpitali}

Z protokołów wizytacyjnych z lat 1805-1806 wynika, że w diecezji żmudzkiej możemy wyróżnić trzy wiodące grupy fundatorów szpitali: duchowieństwo, szlachta (kolatorowie) oraz mieszczanie, nazywani w lustracjach dziekańskich parafianami. Przy tworzeniu przytułków dla ubogich dość częstym zjawiskiem były inicjatywy wspólnie podejmowane przez duchowieństwo $\mathrm{z}$ wiernymi czy też $\mathrm{z}$ fundatorami świeckimi. W kilku przypadkach mamy także do czynienie $\mathrm{z}$ fundacjami klasztornymi.

Jak wynika z obliczeń tabelarycznych, w interesującym nas okresie szpitale najczęściej fundowało duchowieństwo diecezjalne. $Z$ fundacji

\footnotetext{
${ }^{28}$ L. Królik, Organizacja diecezji tuckiej i brzeskiej od XVI do XVIII wieku, Lublin 1983, s. 342-343; S. Litak, Parafie w Rzeczypospolitej..., dz. cyt., s. 344.

${ }^{29}$ Obliczenia na podstawie S. Litak, Parafie w Rzeczypospolitej..., dz. cyt., s. 338342; S. Litak, Atlas Kościoła łacińskiego..., dz. cyt., s. 86-91; M. Surdacki, Protestanci a rozwój szpitali w Wielkopolsce Zachodniej w XVII o XVIII wieku, „Odrodzenia i reformacja w Polsce" 1991, t. 36, s. 201.
} 
Szpitale diecezji żmudzkiej na początku XIX stulecia

Tab. 3. Fundatorzy szpitali w diecezji żmudzkiej według raportów dziekańskich w latach 1805-1806

\begin{tabular}{|c|l|c|c|}
\hline Lp. & \multicolumn{1}{|c|}{ Fundator } & Liczba & \% \\
\hline $\mathbf{1 .}$ & proboszcz & 32 & 26,8 \\
\hline $\mathbf{2 .}$ & kolator/kolatorzy (szlachta) & 22 & 18,4 \\
\hline $\mathbf{3 .}$ & proboszcz i mieszczanie & 19 & 15,9 \\
\hline $\mathbf{4 .}$ & mieszczanie (parafianie) & 16 & 13,4 \\
\hline $\mathbf{5 .}$ & fundator i mieszczanie & 2 & 1,6 \\
\hline $\mathbf{6 .}$ & klasztor & 5 & 4,2 \\
\hline $\mathbf{7 .}$ & proboszcz i kolator & 1 & 0,8 \\
\hline $\mathbf{8 .}$ & altarzysta & 2 & 1,6 \\
\hline $\mathbf{9 .}$ & brak danych & $\mathbf{2 0}$ & 16,8 \\
\hline & Razem & $\mathbf{1 1 9}$ & $\mathbf{1 0 0}$ \\
\hline
\end{tabular}

Źródło: LIVA, f. 669, ap. 2, b. 221, k. 1-120, 220-651.

duchownych założone zostały 34 placówki dla ubogich $(28,5 \%)$. W przeważającej większości erygowali je proboszczowie - 32. W dwóch przypadkach koszty budowy pokrył altarzysta pracujący przy kościele filialnym w Kużach (dek. Janiszki) ${ }^{30}$ i Wodokatch (dek. Kroki) ${ }^{31}$. Jeśli do liczby tej dodamy fundacje wspólne, wkład duchowieństwa w zakładanie szpitali zdecydowanie wzrasta. Duchowni samodzielnie czy też przy współudziale parafian i kolatorów brali udział przy tworzeniu aż 54 szpitali (45,3\%). Przykładem jedynej wspólnej fundacji proboszcza z kolatorem jest szpital w Sałantach (dek. Szkudy) ${ }^{32}$.

Stosunkowo duży wkład duchowieństwa w zakładaniu szpitali wynikał niejako z panujących wówczas uwarunkowań społecznych. Dla ubogich skupionych $\mathrm{w}$ miastach i wsiach kościół był jedynym miejscem, gdzie mogli liczyć na pomoc. W zamian za udzielone im wsparcie wykonywali oni pracę na rzecz parafii, utrzymując porządek $\mathrm{w}$ kościele, stróżując itp. Proboszczowie starali się zatrzymać takie osoby przy kościele, zapewniając dach nad głową w budynkach należących do parafii lub budując dla nich przy kościele osobny dom. W takim trybie proboszczowie zostawali fundatorami szpitala ${ }^{33}$. Wytłumaczeniem tego zjawiska może być także czas powstania i struktura raportów

\footnotetext{
${ }^{30}$ LIVA, f. 669, ap. 2, b. 221, k. 423.

31 Tamże, k. 332.

32 Tamże, k. 386.

${ }^{33} \mathrm{Na}$ uwarunkowanie to zwrócił uwagę Z. Góralski w monografii poświęconej szpitalom na Lubelszczyźnie przed rozbiorami, zob. Z. Góralski, Szpitale na Lubelszczyźnie w okresie przedrozbiorowym, Warszawa-Łódź 1982, s. 29.
} 
wizytacyjnych. Rzadko kiedy odwołują się one do dziejów dawniejszych, a jeśli już, to przy okazji wyszczególnienia kapitałów lub gruntów zapewnionych szpitalom w dokumencie fundacyjnym. Dość często brak w nich także informacji na temat dat powstania szpitali. Opisy dotyczą stanu placówek przeważnie w chwili wizytacji, ewentualnie kilku czy kilkunastu lat wstecz. Tym sposobem proboszcz, który wybudował lub wyremontował budynek szpitalny istniejący w czasie wizyty dziekana, stawał się automatycznie twórcą fundacji. Nic więc dziwnego, że wśród fundatorów szpitali na Żmudzi w interesującym nas okresie nie spotykamy królów, biskupów i wyższego duchowieństwa. Chociaż wiemy, że takowe fundacje istniały ${ }^{34}$.

Darczyńcami szpitali była też szlachta. Fundacji takich istniało $22(18,4 \%)$. Niestety, jedynie $\mathrm{w}$ nielicznych przypadkach potrafimy ustalić rzeczywistych kolatorów. Fundatorem szpitala w: Wiekszniach był Adam Górski, starosta wiekszniański ${ }^{35}$; Poszołtuniu (dek. Botoki) Marianna Wereszczyńska, sędzina grodzka inflancka; Sałantach (dawniej Skiłondziach) (dek. Szkudy) - proboszcz ks. Bohuszewicz i Anna Wojna, starościna uzwętowska ${ }^{36}$; Datnowie (dek. Kroki) - Eustachy i Teresa Chrapowiccy, instygatorowie królewscy ${ }^{37}$. W pozostałych opisach podano jedynie kategorie: „kolator” lub „fundator” bez wyszczególnienia nazwisk i piastowanych godności. Trzecią grupę ofiarodawców stanowili mieszczanie. Na ich koszt wybudowano 16 szpitali $(13,4 \%)$, a przy ich pomocy kolejnych $22(18,4 \%)$, co łącznie daje liczbę 38 szpitali $(31,9 \%)$. Obiekty te wybudowano przy zaangażowaniu całej wspólnoty parafialnej. Trudno raczej zakładać, by pojedynczy mieszczanin mógł sam sfinansować założenie szpitala. Inicjatorem oczywiście pozostawał proboszcz, który z powodu szczupłości uposażenia musiał odwołać się do ofiarności i pomocy wiernych. Stosunkowo nieliczny udział w zakładaniu szpitali na Żmudzi miały klasztory. Przy pięciu placówkach, z wszystkich szesnastu, odnotowujemy taką właśnie fundację $(31,25 \%)$. W skali całej diecezji uzyskana liczba stanowi niewielki odsetek wynoszący niespełna $(4,2 \%)$. Miejscowości, w których funkcjonowały szpitale wybudowane na koszt zakonników, to: Cytowiany w dekanacie Szydłów (bernardyni) ${ }^{38}$, Datnów w deka-

\footnotetext{
${ }^{34}$ F. Augustajtys, Szpitale w Polsce, [w:] Z. Chełmicki (red.), Podręczna encyklopedia kościelna, t. 39-40, Poznań-Warszawa 1914, s. 10.

${ }^{35}$ LIVA, f. 669 , ap. 2, b. 221 , k. $455 \mathrm{v}$.

36 Tamże, k. 386.

37 Tamże, k. 599v.

${ }_{38}$ Tamże, k. 606-610.
} 
nacie Kroki (bernardyni) ${ }^{39}$, Kiejdany w dekanacie Kroki (karmelici trzewiczkowi) ${ }^{40}$, Linków w dekanacie Janiszki (karmelici trzewiczkowi) ${ }^{41}$, w Worniach przy katedrze (rochoici) ${ }^{42}$.

\section{Uposażenie i fundusze szpitali}

Spośród 119 szpitali w diecezji żmudzkiej w intersującym nas okresie zaledwie $20(16,8 \%)$ posiadało stałe uposażenie. Należały do nich szpitale w następujących miejscowościach: Wornie - przy katedrze, Chwałojnie i Twery (dek. Wornie), Rosienie i Jurbork (dek. Wielona), Kroki i Krakinów (dek. Kroki), Szydłów (dek. Szydłów), Szkudy, Sałanty - szpital dla mężczyzn i szpital dla kobiet (dek. Szkudy), Janiszki i Stare Żagory (dek. Janiszki), Płungniany (dek. Retów), Olsiady, Kęstajcie (dek. Olsiady), Krutowiany, Tryszki (dek. Wieksznie), Łukniki (dek. Wornie), Dowiatów (dek. Szadów). Z ciekawą sytuacją mamy do czynienia w ostatniej z wymienionych miejscowości. Mikołaj Kłopotowski zapisem testamentowym z 16 stycznia 1796 r. przekazał 1000 talarów na budowę szpitala dla czterech ubogich przy tamtejszym kościele filialnym. Wykonawcą woli fundatora miał być Jerzy Dowiat, który z niewiadomych przyczyn nie wykonał woli zmarłego. Szpital nigdy nie powstał, chociaż posiadał fundusze ${ }^{43}$. Uposażenie szpitali stanowiły najczęściej grunty i sumy pieniędzy zapisane przez fundatorów $\mathrm{w}$ akcie erekcyjnym, a także $\mathrm{w}$ wyniku późniejszych zapisów testamentowych. Na uposażenie w gruntach składały się pola o różnej wielkości, z jednym lub dwoma folwarkami, lasami, łąkami, ogrodami itp. Rozpiętość powierzchni dóbr szpitalnych wynosiła od 1 do ponad 18 włók. Najobszerniejsze grunty posiadał szpital przy kościele parafialnym $\mathrm{w}$ Krokach. W sumie należały do niego grunty o areale ponad 18 włók i 38 morgów oraz bliżej nieokreślonej wielkości łąki. Posiadana ziemia z czynszów i dzierżaw przynosiła szpitalowi w Krokach roczny dochód w wysokości 143 rubli i 73 kopiejki ${ }^{44}$. Szpital przy kościele parafialnym w Kęstajciach (dek. Olsiady) posiadał 18 włók ${ }^{45}$, w Worniach (przy kościele katedralnym) - ponad 6 włók ${ }^{46}$,

\footnotetext{
${ }^{39}$ Tamże, k. 599v.

${ }^{40}$ Tamże, k. $597 \mathrm{v}$.

${ }^{41}$ Tamże, k. 629-629v.

${ }^{42}$ Tamże, k. 640-641v.

${ }^{43}$ LIVA, f. 669, ap. 2, b. 221, k. 489v.

${ }_{44}$ Tamże, k. 642.

45 Tamże, k. 644v.

46 Tamże, k. 640.
} 
w Szkudach - 6 włók, a roczny dochód w wysokości 54 rubli ${ }^{47}$. Do szpitala w Jurborku (dek. Wielona) należała jedna włóka, „na której ogrody, reszta ziemi nieurodzajnej piaskiem zasypanej z nad Niemna leży odłogiem"48. Grunty posiadał także szpital w Tryszkach (dek. Wieksznie). Trudno powiedzieć, o jakie ilości ziemi chodzi, ponieważ połączone one były z gruntami parafialnymi. Wiemy jedynie, że proboszcz z dochodów od nich uzyskanych miał siedmiu ubogich ,utrzymać, wyżywić i odziać" 49 .

Obok nadań gruntowych szpitale miały zagwarantowane przychody z sum pieniędzy złożonych na procent czy też pod zastaw hipoteczny (werdykafy). Wchodziły tutaj także zapisy testamentowe oraz inne uczynione przez pobożnych ofiarodawców w późniejszym okresie. Fundusze takie posiadały szpitale w: Krutowianach (dek. Wieksznie) - 4635 rubli $^{50}$, Kęstajciach - 1485 rubli $^{51}$, Worniach przy katedrze - 3004 ruble $^{52}$, Twerach - 1900 rubli $^{53}$, Janiszkach - 1177 rubli 20 kopiejek $^{54}$, Olsiadach - 495 rubli $^{55}$, Rosieniach - 495 rubli $^{56}$, Szydłowie - 195 rubli $^{57}$, Płungnianach -180 rubli $^{58}$, Sałantach szpital męski - 153 ruble $^{59}$, Szawlach - 106 rubli 87 kopiejek $^{60}$, Starych Żagorach - 75 rubli $^{61}$. Największy przychód od wymienionych kapitałów osiągał szpital przy katedrze wornieńskiej oraz szpital w Kęstajciach. W pierwszym przypadku wynosił on w skali roku 246 rubli 237 kopiejek $^{62}$, w drugim - 158 rubli 45 kopiejek $^{63}$.

Pozostałe szpitale notowały o wiele mniejsze zyski. Przykładowo, dochód roczny szpitala w Olsiadach od sumy 495 rubli, lokowanej na kahale pługniańskim na 7\%, wynosił 34 ruble i 65 kopiejek. Całą uzyskaną sumę proboszcz przeznaczał na wyżywienie i ubrania dla

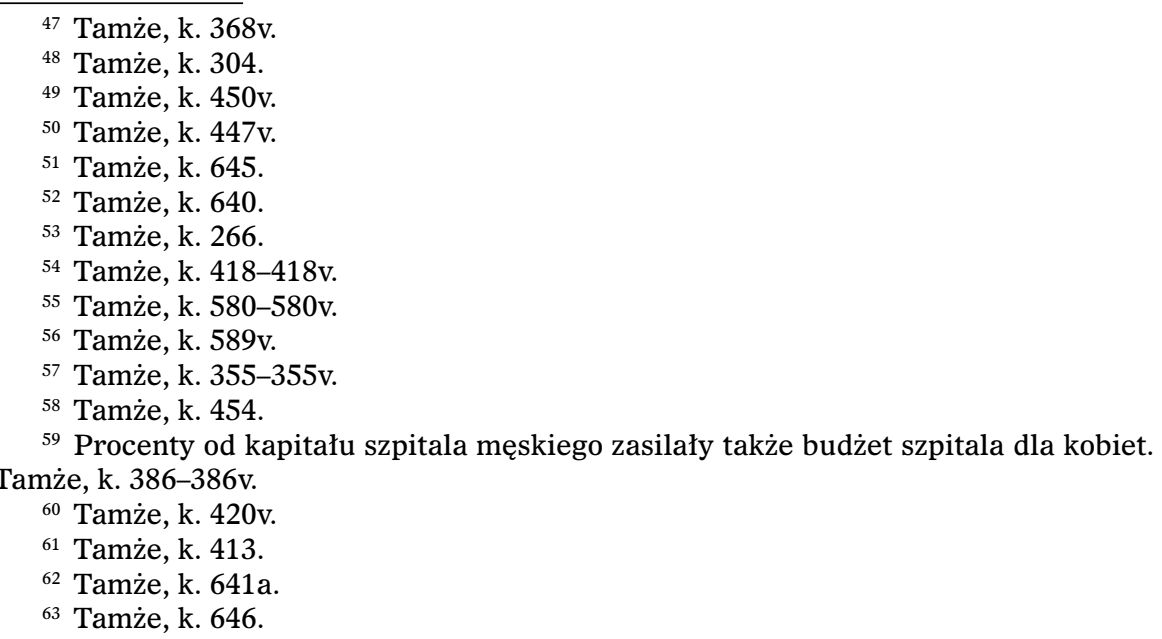


ubogich $^{64}$. Szpital dla mężczyzn w Sałantach od sumy 153 rubli złożonej na $7 \%$ na kahale sołtanowskim zyskiwał roczny przychód w wysokości 10 rubli i 71 kopiejek. $Z$ tych pieniędzy miejscowy proboszcz raz na trzy lata zaopatrywał pięciu ubogich w płaszcze ${ }^{65}$. Dochód szpitala w Starych Żagorach od 7\% z sumy 75 rubli zabezpieczonej na dobrach ziemskich, wraz z sumami należącymi do kościoła parafialnego, przeznaczano każdego roku na zakup odzieży dla ubogich ${ }^{66}$. W Chwałojniach roczny dochód szpitala połączony był częściowo z dochodami klasztoru i wynosił 23 ruble i 85 kopiejek $^{67}$.

Trzeba podkreślić, że rzeczywiste przychody z gruntów czy kapitałów pieniężnych były znacznie mniejsze niż powinny, jeśli w ogóle docierały do szpitali. Część dóbr fundacyjnych przepadła. Część ziemi wypuszczano w dzierżawę, co już pomniejszało płynące z niej zyski. Dodatkowo w efekcie rozbiorów większość gruntów zmieniła właścicieli, a sumy oddane na procent przepadły lub utraciły swą pierwotną wartość. Nowi właściciele przeważnie nie wypłacali czynszów, podobnie jak instytucje, którym powierzano pieniądze. Ściąganie zaległości wymagało uporządkowania spraw własności w nowych realiach politycznych, a co za tym idzie - udowodnienia swoich racji przed sądem. Procesy wszczynane przez proboszczów czekały dopiero na rozstrzygnięcie. $\mathrm{Z}$ tego też powodu część funduszy należnych szpitalom pozostawało jedynie zapisem bez pokrycia. W takiej sytuacji pozostawały szpitale w: Janiszkach, Krakinowie, Krokach, Rosieniach, Szawlach i Szkudach.

Przytoczmy kilka przykładów. Wysoką, jak się wydaje, sumę 4635 rubli pochodzącą z dwóch zapisów dla szpitala w Krutowianach już wówczas uznawano za niepewną. Szpital pobierał jedynie procent $\mathrm{z}$ tytułu drugiego nadania na kwotę 135 rubli, w wysokości 8 rubli i 11 kopiejek $^{68}$. Podobnie szpital w Rosieniach miał zagwarantowany dochód od 495 rubli, ulokowanych na kahale rosieńskim. W $1793 \mathrm{r}$. zaprzestano odprowadzać procent od tej kwoty. Dopiero wyrok sądu ziemskiego rosieńskiego, do którego skargę skierował klasztor, nakazał Żydom wypłacić w ratach przez sześć lat należny szpitalowi procent wraz z odsetkami, począwszy od 1806 r. ${ }^{69} \mathrm{Z}$ podobnymi problemami borykał się szpital w Szawlach. Tutaj z kolei rocznego czynszu od

\footnotetext{
${ }^{64}$ Tamże, k. 580-580v.

65 Tamże, k. 386v.

66 Tamże, k. 413.

67 Tamże, k. 277.

68 Tamże, k. 447v.

69 Tamże, k. 589v.
} 
1801 r. nie odprowadzał nowy właściciel Ekonomii Szawelskiej książę Płaton Zubow, jeden z faworytów cesarzowej Katarzyny II $^{70}$. Szpital w Krakinowie miał zagwarantowane na mocy dokumentu fundacyjnego z 1703 r. utrzymanie trzech biednych dzwonników z obowiązkiem codziennego śpiewania różańca. Na ten cel fundator przekazał po trzy pudy żyta, owsa i jęczmienia, trzy korce grochu oraz 3 ruble lokowane na procent. Nadania zostały zabezpieczone na dobrach ziemskich. Mimo tego w 1790 r. dziedzic dóbr zaprzestał opłacania rocznych czynszów na rzecz szpitala ${ }^{71}$.

Zdecydowana większość szpitali żmudzkich pozostawała bez żadnych środków utrzymania 99 (83,1\%). Jedynym ich dochodem była jałmużna. Do obowiązków proboszcza należała troska o budynek oraz zapewnienie szpitalnikom dachu nad głową. $\mathrm{O}$ chleb i inne niezbędne do przeżycia środki musieli oni postarać się we własnym zakresie. Żyli więc, jak najczęściej podają wizytacje, „z jałmużny i opatrzenia”, „z jałmużny i łaski” parafian, dobrodziejów, proboszcza, ewentualnie proboszcza i parafian oraz ,z jałmużny i pracy rąk swoich" "72. Zbieranie jałmużny stanowiło dla ubogich szpitalnych główne zajęcie, obok modlitwy i „usługiwania kościołowi”’3. Wyczekiwanie na daninę najczęściej odbywało się przed wejściem do świątyni przed nabożeństwami i po ich zakończeniu. Zabraniano natomiast chodzenia w czasie trwania Służby Bożej. Zbiórki na szpitale prowadzono także przy pomocy skarbonek. Jak wiemy z dotychczasowych badań, większość szpitali epoki przedrozbiorowej posiadało takie skarbonki umieszczone w kościołach lub miejscach publicznych ${ }^{74}$. Co ciekawe, wizytacje żmudzkie wymieniają jedynie dwa kościoły, w których znajdowały się tego rodzaju naczynia. Były to świątynie $w$ Masiadach $^{75}$ i Szawlanach $^{76}$. Wydaje się, że i na Żmudzi występowały one powszechnie. Widocznie dziekani podczas wizytacji uważali skarbony za normalne wyposażenie kościoła i z tego powodu nie widzieli potrzeby informowania o ich istnieniu $\mathrm{w}$ sporządzanych przez siebie raportach. Dodatkowe źródło żywności stanowiły ogródki warzywne na placach plebańskich, uprawiane sezonowo przez ubogich. Najczęściej to, co

\footnotetext{
${ }^{70}$ Tamże, k. $420 \mathrm{v}$.

${ }^{71}$ Tamże, k. 331.

72 Tamże, k. 50, 351v, $567 \mathrm{v}$.

73 Tamże, k. 396v.

${ }^{74}$ Z. Góralski, dz. cyt., s. 104; A. Kopiczko, Szpitalnictwo na Warmii w XVI-XVIII wieku, [w:] M. Dąbrowska, J. Kruppè (red.), Szpitalnictwo w dawnej Polsce, Warszawa 1998, s. 104.

${ }^{75}$ LIVA, f. 669 , ap. 2, b. 221 , k. $57 \mathrm{v}$.

${ }^{76}$ Tamże, k. 84v.
} 
udało się uzbierać w skarbonkach w wyniku prowadzonych kolekt czy też wyhodować, dzielono między wszystkich podopiecznych przytuł$\mathrm{ku}^{77}$. Trzeba pamiętać, że jałmużna i środki ze skarbon nie stanowiły stałego dochodu i zależały od hojności ofiarodawców. Mimo wszystko pochodzące $\mathrm{z}$ nich wpływy pozwalały na egzystowanie szpitali.

\section{Budynki szpitalne}

Silne związki szpitala z parafią powodowały, że budynki szpitalne budowano przeważnie na placu w pobliżu kościoła obok plebanii. Wyjątek od tej reguły w diecezji żmudzkiej stanowiły dwa szpitale. Pierwszy to szpital braci rochitów, pierwotnie usytuowany przy katedrze wornieńskiej, a pod koniec XVIII w. przeniesiony za miasto ${ }^{78}$. Odwrotnie szpital w Jurborku - znajdował się poza miastem nad rzeką Niemen, niedaleko wsi Kulmiany. Dopiero w 1806 r. został przeniesiony bliżej kościoła parafialnego na dziedziniec plebański ${ }^{79}$. Wygląd zewnętrzny oraz wyposażenie budynków zależały od możliwości finansowych parafii. Podobnie jak ich stan zachowania. Na Żmudzi $\mathrm{w}$ interesującym nas okresie prawie wszystkie szpitale wybudowano z drewna, bo aż 117 ze wszystkich 119 (98,3\%). Były to budynki mieszczące zazwyczaj: od jednej do czterech stancji (izb) z piecami do ogrzewania, kilka komórek (służących za sypialnie) i jednej lub kilku izb bocznych (tzw. bokówek), ewentualnie sień ${ }^{80}$. Niektóre szpitale, obok zwykłych miejsc mieszkalnych, posiadały zamknięte izolatki, tzw. tiurmy dla obłąkanych ${ }^{81}$. Zdarzały się również budynki z większą liczbą pomieszczeń. Szpital w Użwentach posiadał osiem stancji ciepłych i osiem zimnych ${ }^{82}$. Budynek szpitalny w Masiadach miał „stancji ze składami czternaście" ${ }^{83}$. Szpitale w Krutowianach i Szwekszniach mieściły po dwanaście stancji ${ }^{84}$. Nieco inaczej niż wszystkie wyglądał budynek szpitalny w Kęstajciach (dek. Olsiady) i Iłokach (dek. Szkudy). Drewniany i dwupiętrowy gmach szpitala w Kęstajciach przylegał do kaplicy. Dolną kondygnację, w której urządzono dwie izby, zajmowali ubodzy. Na górnej znajdowały się „stancyjki letnie dla braci rochitów" sprawujących nadzór nad przytułkiem. Obok szpitala stał

\footnotetext{
77 Z. Góralski, dz. cyt., s. 158; S. Litak, Parafie w Rzeczypospolitej.., dz. cyt., s. 356.

${ }_{78}$ M. Wołonczewski, Biskupstwo żmujdzkie, Kraków 1898, s. 188.

${ }^{79}$ LIVA, f. 669, ap. 2, b. 221, k. 20v, 304.

${ }^{80}$ Przykładowy opis budynku szpitalnego zob. LIVA, f. 669, ap. 2, b. 221, k. 27v.

${ }^{81}$ Tamże, k. 580.

82 Tamże, k. 286v-287.

${ }^{83}$ Tamże, k. 393.

${ }^{84}$ Tamże, k. 447v, 535.
} 
budynek przeznaczony na mieszkanie kapelana, dzwonnica oparta na słupach, oficyna dla czeladzi oraz budynki gospodarcze. Całość otaczał drewniany parkan ${ }^{85}$. Do jednego z końców budynku szpitalnego w Iłokach dobudowany był drewniany dom mieszkalny, pokryty dachówką z dwoma izbami mieszkalnymi. Całość kompleksu tworzyła litere „„”. Dom ten wybudowała jedna z parafianek ,dla własnej wygody" 86 .

Zabudowania szpitalne w ogromnej większości były pokryte słomą, rzadziej gontem i „dranicami”, bardzo rzadko zaś dachówką. Na ogół posiadały podłogę wybitą gliną. Tylko w nielicznych przypadkach odnajdujemy informacje o podłodze z desek lub cegły. Zdarzały się także szpitale bez podłogi. Do ogrzewania pomieszczeń służyły piece „ordynaryjne” oraz piece szwedzkie (kaflowe lub z cegły). Dym z pieców odprowadzał komin (murowany lub gliniany) „nad dach wyprowadzony”. Powszechne wyposażenie budynków szpitalnych stanowiły drewniane „stołowania" 87.

W całej diecezji tylko dwa szpitale w Kretyndze i Janiszkach były murowane. Oprócz użycia do ich budowy bardziej trwałych materiałów pod względem kubatury nie odbiegały one znacznie od budynków drewnianych. W gmachach tych mieściło się odpowiednio: cztery izby (Kretynga), dwie izby i dwie komory (Janiszki). Podobnie tylko w dwóch budynkach szpitalnych znajdowały się kaplice. Jednym z nich był wspomniany wyżej szpital w Kretyndze, drugim szpital pozostający pod opieką parafii katedralnej w Worniach. Tak samo jedynie dwa szpitale prowadzone przez braci rochitów w Worniach przy katedrze oraz w Kęstajciach posiadały wydzielone izby dla chorych (infirmierze).

Pod względem konstrukcji wykorzystanego budulca oraz urządzenia wnętrz szpitale żmudzkie w niczym nie odbiegały od budynków szpitalnych w innych diecezjach zarówno w Koronie, jak i na Litwie. Większość szpitali na terenie Lubelszczyzny w okresie przedrozbiorowym wzniesiono $\mathrm{z}$ drewna, murowane zaś stawiano rzadko. Na 38 szpitali, dla których udało się zebrać dane, 32 były drewniane, a tylko 6 murowanych. W przeważającej większości budynki szpitalne posiadały dwie izby $\mathrm{w}$ układzie dwutraktowym $\mathrm{z}$ sienią pośrodku i czasami posiadały pomieszczenia gospodarcze ${ }^{88}$. Podobnie rzecz

85 Tamże, k. 644-644v.

86 Tamże, k. 273-273v.

87 LIVA, f. 669, ap. 2, b. 221, k. 46v, 73, 343v, 386-386v, 413, 417.

88 Z. Góralski, dz. cyt., s. 36-37. Opis szpitala wybudowanego w Urzędowie pod koniec XVIII w. podaje: M. Surdacki, Szpital Świętego Ducha i Św. Leonarda w Urzędowie w XV-XVIII wieku, „Kwartalnik Historyczny” 2004, R. 62, z. 2, s. 12. 
w tym względzie przedstawiała się na przełomie XVIII i XIX w. na Mazowszu. Tam również większość budynków szpitalnych zbudowano z drewna, dachy zaś kryto słomą, rzadziej dranicami. W większości domów szpitalnych przeważały dwie izby z sienią pośrodku, z jedną lub dwoma komorami i alkierzem ${ }^{89}$. W Wielkopolsce Zachodniej spośód 74 szpitali istniejących w latach 1777-1787 aż 65 stanowiło budynku z drewna $(86,5 \%)$. W przeważającej większości były to domy posiadające jedną izbę, sień, kuchnię, spiżarnię i kaplicę. Odsetek domów dwu- lub wieloizbowych był znacznie mniejszy ${ }^{90}$.

Obok wyglądu zewnętrznego i wewnętrznego budynków wizytatorzy informowali o stanie ich zachowania, dzieląc je w swoich raportach na następujące kategorie: nowy, dobry, stary-dobry, stary wymagający remontu, w ruinie, w budowie, spalony. Odpowiednia kondycja techniczna zabudowań wiele mówiła o użyteczności i poziomie życia osób w nich zamieszkujących. Zjawisko to ilustruje poniższe zestawienie.

Większość szpitali w diecezji żmudzkiej to budynki w dobrym lub bardzo dobrym stanie technicznym. Spośród 119 wszystkich istniejących budynków szpitalnych w diecezji wizytatorzy określili stan jako dobry bądź stary-dobry 46 z nich $(38,6 \%)$. Ponadto aż $33(27,7 \%)$ budynki zostały oddane do użytku na kilka lat lub bezpośrednio przed przeprowadzeniem lustracji (w wizytacjach nazywane jako nowe). Dodatkowo w budowie pozostawało siedem kolejnych przytułków: Szku$\mathrm{dy}^{91}$, Nowe Żagory ${ }^{92}$, Sałaty ${ }^{93}$, Pogromoncie ${ }^{94}$, Żydyki ${ }^{95}$, Szawlany ${ }^{96}$, Wodokty $^{97}$, Poszuszwie ${ }^{98}$. W grupie szpitali nowych i w stanie budowy dwa szpitale otrzymały w raportach wizytacyjnych status ,wspaniały" (Łajżew ${ }^{99}$, Poszułaty ${ }^{100}$ ). Zaobserwowany rozkwit szpitalnictwa wpisywał się w trwający od końca XVIII w. ogólny proces rozwoju diecezji. Biskup J.A. Giedroyć kontynuował działania charytatywne

\footnotetext{
${ }^{89}$ A. Woźniak, Szpitale wiejskie na Mazowszu w końcu XVIII wieku i poczatku XIX wieku, [w:] M. Dąbrowska, J. Kruppè (red.), Szpitalnictwo w dawnej Polsce, Warszawa 1998, s. 79.

${ }^{90}$ M. Surdacki, Opieka społeczna w Wielkopolsce Zachodniej w XVII i XVIII wie$k u$, Lublin 1992, s. 208-209, 220.

${ }^{91}$ LIVA, f. 669, ap. 2, b. 221, k. 386v.

${ }_{92}$ Tamże, k. $414 \mathrm{v}-415$.

${ }_{93}$ Tamże, k. 433v.

${ }_{94}$ Tamże, k. 496v.

95 Tamże, k. $557 \mathrm{v}$.

96 Tamże, k. 489.

97 Tamże, k. 332.

98 Tamże, k. 324.

99 Tamże, k. 445.

100 Tamże, k. 85v.
} 
Marek Hałaburda

Tab. 4. Budynki szpitalne $\mathrm{w}$ świetle raportów dziekańskich $\mathrm{z}$ lat 18051806

\begin{tabular}{|c|c|c|c|c|c|c|c|c|c|}
\hline \multicolumn{7}{|c|}{ Stan zachowania budynków szpitalnych } & \multirow{2}{*}{$\begin{array}{c}\text { Ra- } \\
\text { nem }\end{array}$} \\
\hline 33 & 31 & 15 & 24 & 6 & 7 & 1 & 1 & 1 & 119 \\
\hline 27,7 & 26,0 & 12,6 & 20,1 & 5,0 & 5,8 & 0,8 & 0,8 & 0,8 & $\%$ \\
\hline
\end{tabular}

Źródło: LIVA, f. 669, ap. 2, b. 221, k. 1-120, 220-651.

zapoczątkowane przez swojego poprzednika S.F. Giedroycia. Wydał szereg zarządzeń dotyczących opieki nad biednymi na terytorium zarządzanej przez siebie diecezji. Nawoływał do zakładania przytułków. Przypominał, że erygowanie i utrzymanie istniejących szpitali oraz dbanie o szpitalników należy do bezpośrednich obowiązków proboszcza. Określał zasady postępowania wobec ubogich w parafiach. Udzielał konkretnych wskazówek, wspomagał, ale także kontrolował wprowadzenie $\mathrm{w}$ życie proponowanych rozwiązań ${ }^{101}$. Jak widać, program duszpasterski nakreślony przez ordynariuszy żmudzkich przynosił wymierne efekty.

Należy tutaj podkreślić, że proces rozwoju szpitalnictwa i opieki społecznej zapoczątkowany $\mathrm{w}$ epoce stanisławowskiej $\mathrm{w}$ diecezji żmudzkiej rozpoczął się później. Kiedy pod koniec XVIII i na początku XIX stulecia w większości polskich diecezji pod zaborami następował powolny zanik szpitali-przytułków, na Żmudzi zauważamy tendencje odwrotne ${ }^{102}$. Szpitale żmudzkie $\mathrm{w}$ przeważającej większości nadal wypełniały rolę schronisk dla osób pokrzywdzonych przez los, leczeniem zaś zajmowały się na marginesie w ramach szeroko rozumianej troski o swoich pensjonariuszy. Zdecydowana większość przytułków pozostawała, tak jak dawniej, pod zarządem proboszcza. Zgodnie z raportami wizytacyjnymi jedynie szpital w Krokach podlegał Komisji Szpitalnej ${ }^{103}$. Szpital w Kielmach pozostawał pod dozorem

\footnotetext{
${ }^{101}$ A. Prašmantaitè, dz. cyt., s. 12.

102 Zapoczątkowane w $1775 \mathrm{r}$. przez polski sejm reformy szpitalnictwa kontynuowały władze zaborcze. W Wilnie pod koniec XVIII w. na mocy rozkazu gubernatora Repnina zlikwidowano kilka małych szpitali. Chorych z zamykanych placówek przenoszono do szpitali generalnych. W 1796 r. szpital św. Marii Magdaleny wraz z całym funduszem został przeniesiony do nowo utworzonego szpitala generalnego św. Jakuba. Taki sam los spotkał szpitale św. Trójcy oraz św. Rocha, również przeniesione wraz z funduszami do szpitala św. Jakuba. W. Zahorski, Pierwsze szpitale wileńskie (Kartka z historji Szpitalnictwa w Wilnie), „Pamiętnik Wileńskiego Towarzystwa Lekarskiego” 1925, R. 1, z. 1, s. 67-70.

${ }^{103}$ LIVA, f. 669 , ap. 2, b. 221 , k. 253v.
} 
proboszcza i świeckiego prowizora zgodnie z zaleceniami rzeczonej komisji ${ }^{104}$. W Twerach tamtejszym szpitalem zawiadywali świeccy prowizorowie wyznaczeni przez proboszcza ${ }^{105}$. Pewne oznaki zmian zachodzących w szpitalnictwie na Żmudzi zauważamy na początku stulecia. W 1801 r. J.A. Giedroyć wydał dekret nakazujący dziekanom i proboszczom powołanie komisji parafialnych do spraw szpitali. Do obowiązków komisji należało m.in. przeprowadzenie rejestracji żebraków przebywających na terenie parafii i konieczności dokonania ich selekcji. Selekcja ubogich miała na celu odróżnienie prawdziwych ubogich posługujących przy kościele parafialnym, chorych i kalek potrzebujących pomocy od żebraków-włóczęgów, którzy przybywali do parafii z odległych stron. Osoby najbardziej potrzebujące nakazano umieścić $\mathrm{w}$ rejestrze szpitalników, zdrowych $\mathrm{w}$ rejestrze parafialnym z możliwością zbierania jałmużny na terenie własnej parafii. Ubogich mogących zarobić na swoje utrzymanie kazano wysłać do pracy, przybyszów zaś odesłać do parafii, z której przybyli ${ }^{106}$.

Po raz kolejny na temat kwestii porządkujących sprawy szpitalnictwa na terenie diecezji biskup żmudzki wypowiedział się w liście pasterskim z 29 maja $1811 \mathrm{r}$. W obszernym dokumencie skierowanym do duchowieństwa i wiernych przedstawił w 11 paragrafach: prawa i obowiązki zarządców kościelnych; sprawy związane z prowadzeniem rachunków szpitali; prawa i obowiązki urzędników szpitalnych; prawa opiekunów i podopiekunów szpitalnych; normy dotyczące domów szpitalnych; reguły postępowania i obowiązki względem ubogich; regulamin dla ubogich przebywających w szpitalach; normy w sprawie ubogich na terenie parafii; uczestnictwo ubogich szpitalnych w nabożeństwach ${ }^{107}$. Biskup żmudzki przypomniał także o obowiązku prowadzenia rejestrów ubogich szpitalnych i ubogich parafialnych, a także dokonania podziału na prawdziwych ubogich i włóczęgów, „próżniaków” oraz o konieczności odsyłania przybyszów do macierzystej parafii $^{108}$. Rozporządzenia ordynariusza wynikały z potrzeby dostosowania norm prawnych biskupstwa do praw obowiązujących w Imperium Rosyjskim. W tym przypadku chodziło konkretnie o regulament dla

${ }^{104}$ Tamże, k. 338v-339.

105 Tamże, k. 12.

${ }^{106}$ LIVA, f. 669, ap. 2, b. 678, k. 33v-34v; A. Prašmantaitè, Žemaičiu vyskupas Juozapas..., s. 212-213.

107 Urzadzenie szpitalow parafijalnych $w$ dyecezyi żmudzkiej, „Dzieje Dobroczynności Krajowej i Zagranicznej z Wiadomościami Wydoskonaleniu Jey Służącemi” 1820, t. 1, s. 88-97.

108 Tamże, s. 89-90. 
duchowieństwa rzymskokatolickiego zatwierdzony przez cara Aleksandra I w dniu 13 listopada 1801 r. oraz ukaz carski z 1807 r. zakazujący pod surową karą przemieszczania się włóczęgów z jednego miasta do drugiego, z jednej parafii do drugiej. Zakaz ten obejmował również opuszczanie własnego kościoła parafialnego celem odbycia pielgrzymki czy też uzyskania odpustu ${ }^{109}$.

Co zrozumiałe, nowe przepisy wprowadzone w $1801 \mathrm{r}$. nie od razu znajdowały odzwierciedlenie $\mathrm{w}$ funkcjonowaniu szpitali. W wizytacjach dziekańskich z lat 1805-1806 tylko przy dwóch szpitalach zamieszczono rejestr szpitalników z podaniem ich wieku i czasu przebywania w placówce. Oznaki zmian zauważamy po kilkunastu latach. W lustracji przeprowadzonej przez biskupa J.A. Giedroycia w $1821 \mathrm{r}$. spisy ubogich (imiona i nazwiska, często z zaznaczeniem sprawowanej funkcji) znajdujemy już przy wszystkich szpitalach ${ }^{110}$. Ograniczenie skali włóczęgostwa i żebractwa nie miało wpływu na zmianę sieci szpitalnej w diecezji żmudzkiej. Większość przytułków dla ubogich działających w latach 1805-1806 przy kościołach parafialnych i filialnych po upływie 15 lat funkcjonowała nadal ${ }^{111}$. Wyjątek stanowią tutaj szpitale strawione przez pożar lub zniszczone upływem czasu ${ }^{112}$. $\mathrm{W}$ raportach powizytacyjnych nie natrafiamy natomiast na przekazy o likwidacji przytułków.

Liczba świeżo wybudowanych szpitali wyjaśnia nam również, dlaczego $\mathrm{w}$ diecezji żmudzkiej mamy do czynienia z kompletnym brakiem prepozytur szpitalnych. Szpitale prepozyturalne stanowiące samodzielne instytucje $\mathrm{z}$ własnym beneficjum, kościołem i prepozytem oraz posiadające trwałe podstawy materialne, zapewnione w dokumencie fundacyjnym, zaczęły powstawać pod koniec XIII w.

109 Tamże, s. 89, 91

${ }^{110}$ LIVA, f. 669, ap. 2, b. 225, k. 5v, 20, 30, 34v.

111 Tamże, f. 669, ap. 2, b. 225, k. 5-515v; tamże, f. 669, ap. 2, b. 226, k. 1-664; tamże, F. 669 , ap. 2, b. 227, k. 1-628. Mylny obraz na temat stanu szpitali żmudzkich odnajdujemy w raporcie o szpitalach diecezji żmudzkiej przygotowanym na podstawie wizytacji biskupiej z 1821 r. i opublikowanym na łamach pisma „Dzieje Dobroczynności” w 1822 r. Raport ten wymienia jedynie 37 szpitali parafialnych. Zob. Stan szpitalow parafialnych czyli gosod dla ubogich $w$ dyecezyi żmudzkiey podług wizyty jeneralnej przez samego biskupa Xiażęcia Józefa Giedroycia w roku 1821 odprawioney, „Dzieje Dobroczynności Krajowey i zagraniczney z wiadomościami ku wydoskonaleniu jey służącemi” 1822, t. 3, kol. 752-769.

${ }_{112}$ Dobrym przykładem jest tutaj szpital w Krokach, który na przestrzeni 15 lat (1806-1821) spłonął dwukrotnie, najpierw w 1809 r. i później po odbudowie w $1818 \mathrm{r}$. LIVA, f. 669, ap. 2, b. 225, k. 4v. Szpital w Wielonie w wizytacji z 1806 r. określany jest jako dobry, 15 lat później został opuszczony przez ubogich z powodu zupełnego zniszczenia. Tamże, f. 669, ap. 2, b. 225, k. 246. 
Gwałtowny ich rozwój nastąpił na początku XIV w. i trwał do końca pierwszej połowy XV w. Był związany ze wzrostem znaczenia mieszczan, co powodowało, że szpitale tego rodzaju powstawały wyłącznie w ośrodkach miejskich. W 1400 r. na obszarze dzisiejszego terytorium Polski funkcjonowało ok. 180 prepozytur szpitalnych, a w samym tylko XV w. powstało ich dodatkowo $210^{113}$. W XVII w. rozpoczął się powolny proces zanikania tego rodzaju fundacji. W XVIII w. należały do rzadkości, a w początkach XIX w. przetrwały już tylko nieliczne prepozytury szpitalne ${ }^{114}$.

Wróćmy do kondycji budynków szpitalnych. Kwalifikujących się do remontu bądź zupełnie zaniedbanych pozostawało w sumie 30 budynków $(25,2 \%)$. Trudno określić różnicę między budynkami wymagającymi naprawy a budynkami w stanie ruiny. Bez względu na stopień zniszczenia wiemy, że zarówno w jednych, jak i drugich ciągle mieszkali szpitalnicy. Wątpliwości budzić może mała liczba szpitali spalonych. Zaledwie dwa takie wypadki notują wizytacje dziekańskie z 1805 r. i 1806 r. (Nowe Żagory ${ }^{115}$ i Meszkucie ${ }^{116}$ ). Wydaje się, że zabudowań strawionych przez żywioł mogło być więcej. Pożary wówczas wybuchały dość często. Biorąc pod uwagę materiał, z którego wznoszono przytułki, powodowały doszczętne zniszczenie budynku. Konieczność wznoszenia nowego gmachu mogła być spowodowana właśnie działaniem żywiołu. Szpitali spalonych należałoby też poszukiwać $\mathrm{w}$ grupie szpitali nowo wybudowanych oraz $\mathrm{w}$ grupie stwierdzającej ich nieistnienie.

Brak szpitala przy kościele nie zawsze świadczył o tym, że ubodzy $\mathrm{w}$ danej parafii pozostawali pozbawieni jakiejkolwiek pomocy. W sytuacji, kiedy budynek szpitalny spłonął, pozostawał w budowie czy też nigdy nie został wzniesiony, starano się otoczyć najbardziej potrzebujących opieką, znajdując im lokale zastępcze. Z taką sytuacją mamy do czynienia w 16 przypadkach $(13,4 \%)$. Było tak w następujących miejscowościach: Besjagoła (dek. Kroki), Budry (dek. Szkudy), Drobiany (dek. Szkudy), Dowiatów (dek. Szadów), Gidryszki (dek. Botoki), Lenkiemy (dek. Szkudy), Łukniki (dek. Wornie), Ławkosody (dek. Wornie), Nowe Żagory (dek. Janiszki), Pacunele (dek. Kroki), Pojurze (dek. Botoki), Poszyle (dek. Botoki), Szaty (dek. Szkudy),

\footnotetext{
${ }^{113}$ M. Dola, Opieka społeczna Kościoła, [w:] B. Kumor, Z. Obertyński (red.), Historia Kościoła w Polsce, t. 1, cz. 1, Poznań-Warszawa 1974, s. 436.

114 M. Surdacki, Opieka społeczna w Polsce do końca XVIII wieku, Lublin 2015, s. $125-126$

${ }^{115}$ LIVA, f. 669 , ap. 2, b. 221 , k. $414 \mathrm{v}$.

116 Tamże, k. 421v. 
Taurogi (dek. Botoki), Żydyki (dek. Olsiady). W wymienionych miejscowościach ubogich rozlokowywano $\mathrm{w}$ domach pozostających własnością parafii (tzw. domy na ,jurydyce kościelnej”), a także szukano im miejsca $\mathrm{w}$ domach gospodarzy, czeladników i zabudowaniach dworskich. Na przykład szpitalnicy ze spalonego szpitala w Nowych Żagorach do czasu ukończenia budowy nowego gmachu „w miasteczku i po wsiach mieli przytulenie"117. Ubodzy usługujący przy kościele filialnym w Szatach mieszkali w „chatach najętych”118, w Taurogach mieli schronienie częściowo w „chałupkach własnych” i częściowo w „domach skarbowych do plebanii należących”"119. Z kolei w Korcianach ubodzy w oczekiwaniu na oddanie do użytku nowego szpitala znaleźli dach nad głową „w chacie u mieszczanina przez proboszcza najętej”" ${ }^{20}$.

\section{Szpitalnicy}

Wedle obliczeń przeprowadzonych na podstawie wizytacji dziekańskich w diecezji żmudzkiej w interesującym na okresie żyło w sumie 1427 ubogich szpitalnych. Z tej liczby 1257 osób przebywało w 119 szpitalach. Pozostałych 170 miało zapewnioną opiekę ze strony parafii poza szpitalami. Najwięcej ubogich przypadało na dekanat Janiszki - 195 (13 szpitali), dalej kolejno dekanaty: Wieksznie - 172 (11 szpitali), Retów - 166 (12 szpitali), szkudy - 135 (10 szpitali), Wornie - 131 (9 szpitali), Szadów - 121 (10 szpitali), Szydłów - 107 (10 szpitali), Botoki - 102 (10 szpitali), Olsiady - 102 (11 szpitali), Kroki - 101 (12 szpitali), Wielona - 95 (11 szpitali).

Przyjmując za wyznacznik płeć: kobieta-mężczyzna (dane ze 113 szpitali), w szpitalach żmudzkich wśród pensjonariuszy większość stanowiły kobiety. Przebywało ich w tym czasie 767, mężczyzn zaś 438. Jeśli porównamy liczbę wiernych w diecezji 336037 z liczbą szpitalników, otrzymamy niewielki procent wynoszący $0,4 \%$. Zarysowany obraz jest nieco mylący. Biorąc pod uwagę terytorium, na jakim rozciągała się diecezja, z całą pewnością możemy stwierdzić, że szpitale nie były w stanie zapewnić opieki wszystkim potrzebującym, a tych było zdecydowanie więcej. Potwierdzają taki stan również źródła. Dobrym przykładem jest tutaj szpital przy kościele parafialnym w Janiszkach. Przebywało w nim 12 szpitalników, 6 kobiet i 6 mężczyzn. Pozostałych

\footnotetext{
117 Tamże, k. 414v-415.

118 Tamże, k. 396v-397.

119 Tamże, k. 495v.

120 Tamże, k. 381v-382.
} 
40 ubogich, których nie pomieścił szpital, mieszkało w swoich „chałupkach" rozrzuconych w mieście ${ }^{121}$.

O liczbie miejsc $w$ szpitalach decydowały uposażenie oraz liczba pomieszczeń szpitalnych. Jak wykazały nasze dotychczasowe badania, zdecydowana większość szpitali nie posiadała stałych dochodów, kubatura budynków była zaś bardzo zróżnicowana. Największe szpitale żmudzkie mieściły od 25 do 31 szpitalników: Poszwityń - 25 (10 mężczyzn i 15 kobiet) ${ }^{122}$, Płungiany - 26 (brak podziału na płeć) ${ }^{123}$, Okmiany - 27 (5 mężczyzn i 22 kobiety) ${ }^{124}$, Szawle - 28 (12 mężczyzn i 16 kobiet) ${ }^{125}$, Wiekszenie - 31 (7 mężczyzn i 24 kobiety) ${ }^{126}$. Do czasu pożaru w szpitalu w Nowych Żagorach dach nad głową zapewnionych miało 46 osób (20 mężczyzn i 26 kobiet) ${ }^{127}$. W najmniejszych przytułkach mieszkało od 1 do 4 osób ${ }^{128}$ : w Wasiliszkach - $1^{129}$, Połanach, Wodoktach, Poszołtuniu, Gintyliszkach, Upinie - po $2^{130}$, Połądze $-3^{131}$, Chwałojniach, Pojurze, Tenieniach - po $4^{132}$.

121 Tamże, k. 417v-418.

122 Tamże, k. 431.

123 Tamże, k. 545.

124 Tamże, k. 440v.

125 Tamże, k. 420v.

${ }^{126}$ Tamże, k. 454v.

127 Tamże, k. 414v-415.

${ }^{128}$ Liczba pensjonariuszy przebywających w poszczególnych szpitalach żmudzkich nie różniła się specjalnie od innych diecezji okresu przedrozbiorowego. Na przykład w diecezji przemyskiej szpitale małe gwarantowały schronienie średnio dla 4-15 ubogich, duże - 15-30. Z. Budzyński, Dzieje opieki społecznej w ziemi przemyskiej $i$ sanockiej (XV-XVIII w.), Przemyśl-Kraków 1987, s. 128. W szpitalach diecezji warmińskiej w XVIII w. przebywało od 1 do 15 ubogich. Pod tym względem wyróżniał się szpital św. Andrzeja w Braniewie, w którym mieszkało 37 pacjentów. A. Kopiczko, dz. cyt., s. 103104. W diecezji płockiej liczba miejsc w tamtejszych szpitalach na przestrzeni XVIII w. w przeważającej większości wahała się od 1 do 12 . K. Błażewicz, Szpitale diecezji płockiej w XVIII wieku, „Notatki Płockie” 2007, t. 47, nr 2/191, s. 10. Z podobną liczbą pensjonariuszy spotykamy się także w niektórych szpitalach działających w większych ośrodkach miejskich. Szpital w Bydgoszczy przy kościele św. Stanisława na przedmieściu Poznańskim w 1808 r. dysponował 20 miejscami. W.K. Korpalska, Sześć wieków opieki zdrowotnej w Bydgoszczy. Od miłosiernych uczynków do instytucji zdrowia publicznego, Toruń 2008, s. 146. Szpital sióstr miłosierdzia przy ul. św. Jana w Krakowie założony w 1715 r. mógł pomieścić ok. 16 chorych. L. Wachholz, Szpitale krakowskie 1220-1920, cz. 2, Kraków 1924, s. 19-20. W wileńskim szpitalu św. Trójcy w 1792 r. leczono 42 chorych, 12 mężczyzn i 30 kobiet. W. Zahorski, dz. cyt., s. 68. Duże szpitale miejskie dysponowały znacznie większą liczbą łóżek. Przykładowo, szpital św. Ducha w Warszawie u schyłku XVIII w. był w stanie przyjąć 119 pacjentów. L. Królik, Szpital św. Ducha w Warszawie od XV do XVIII wieku, zarys dziejów, „Studia Theologica Varsaviensia” 1984, t. 22, nr 2, s. 101, 108.

129 Tamże, k. 322.

${ }^{130}$ Tamże, k. 237v, 322, 509v, 522v.

131 Tamże, k. 401-401v.

132 Tamże, k. 276, 494, 527-527v. 
Miejsca w szpitalach było mniej niż chętnych. Chociaż w większości mieszkali w nich rzeczywiście najbardziej potrzebujący, to dochodziło jednak do nadużyć. W szpitalach proboszczowie lub zakonnicy dość chętnie umieszczali obcych lokatorów. W budynku szpitalnym w Surwiliszkach, w którym mieściły się dwie izby, obok czterech ubogich mężczyzn i trzech kobiet mieszkał organista i zakrystianin ${ }^{133}$. Podobnie jak w Pokrojach w trzech izbach mieszkało dziewięciu ubogich, a także organista i zakrystianin ${ }^{134}$. W Gintyliszkach wraz z dwoma szpitalnikami mieszkanie dzielił organista ${ }^{135}$. W Kontowciach ubodzy mieli do dyspozycji trzy izby z alkierzykiem, czwartą zajmował organista $\mathrm{z}$ żoną ${ }^{136}$. W Telszach wprawdzie szpital nie działał, ale był dom na placu funduszowym, mieszczący osiem izb, które zajmował jeden ,dziad kościelny”, praczka kościelna, organista i kalkancista ${ }^{137}$. Nagminnym zjawiskiem na obszarze diecezji żmudzkiej było wygospodarowywanie w budynkach szpitalnych miejsca na szkołę. W Kretyndze na cztery izby dwie zajmowała szkoła ${ }^{138}$. W Twerach ubodzy ze szpitala mieli do dyspozycji sześć izb, w siódmej urządzono salę szkolną ${ }^{139}$. W domu szpitalnym w Kielmach były cztery izby i cztery komory. Trzynastu szpitalników musiało dzielić te pomieszczenia ze szkołą ${ }^{140}$. W budynku szpitalnym w Krutowianach mieszkało dziewiętnastu ubogich. Do dyspozycji mieli jedenaście izb, w dwunastej działała szkoła i urządzono mieszkanie jej dyrektora ${ }^{141}$. W szpitalu $\mathrm{w}$ Andrzejowie ${ }^{142}$, Butkiszkach ${ }^{143}$, Chwejdanach ${ }^{144}$, Cytowianach ${ }^{145}$, Kulach, Płotele ${ }^{146}$, Powondeniu ${ }^{147}$, Szwekszniach ${ }^{148}$, Wiewirżany ${ }^{149}$, Wojnucie $^{150}$, Żwingiach ${ }^{151}$ w porze zimowej jedną z izb zamieniano na

\footnotetext{
133 Tamże, k. 330.

134 Tamże, k. 485-485v.

135 Tamże, k. 552v.

136 Tamże, k. 571v.

137 Tamże, k. 534.

138 Tamże, k. 627.

139 Tamże, k. 266.

140 Tamże, k. 338v.

141 Tamże, k. 447v.

142 Tamże, k. 540v.

143 Tamże, k. 309.

144 Tamże, k. 524v.

145 Tamże, k. 610.

146 Tamże, k. 576.

147 Tamże, k. 282.

148 Tamże, k. 535.

149 Tamże, k. 537v.

150 Tamże, k. 532v.

151 Tamże, k. 528v.
} 
klasę szkolną ${ }^{152}$. Szkoły w budynku szpitalnym funkcjonowały jeszcze w Gorżdach ${ }^{153}$, Kielmach ${ }^{154}$, Korcianach ${ }^{155}$, Krokach ${ }^{156}$, Nowych Żagorach (do czasu spalenia szpitala) ${ }^{157}$, Płungianach ${ }^{158}$, Radziwiliszkach $^{159}$, Retowie ${ }^{160}$, Siadach ${ }^{161}$, Szakinowie ${ }^{162}$, Szawlach, Trykszlach ${ }^{163}$, Twerach $^{164}$, Użwnetach ${ }^{165}$, Wilkiji ${ }^{166}$, Zamuszu ${ }^{167}$. W Nowym-Mieście wynajem jednej z ośmiu izb szpitalnych na szkołę w okresie Wielkiego Postu stanowił dodatkowe źródło dochodów dla przytułku ${ }^{168}$. Zjawisko wykorzystywania budynków szpitalnych do niewłaściwych celów nie było tylko żmudzką bolączką. Z sytuacjami takimi mamy do czynienia w większości polskich diecezji przedrozbiorowych. Tam również domy szpitalników wykorzystywano na mieszkania dla osób prywatnych organistów, służby kościelnej, duchownych. Zdarzało się także, że pod dachem przytułku mieściła się szkoła parafialna, siedzibę miało bractwo religijne, a nawet karczma ${ }^{169}$.

$\mathrm{Na}$ określenie szpitalników dziekani używali różnych terminów. Najczęściej w raportach wizytacyjnych występują jako „ubodzy” bądź „ubogie dusze”. Pojawiają się także określenia takie, jak „dziady i baby kościelne” oraz „siermięgi” i „dewotki” ${ }^{170}$. Za wyjątkiem liczby ubogich $\mathrm{z}$ podziałem na mężczyzn i kobiety $\mathrm{w}$ dokumentach nie odnajdujemy dodatkowych informacji na ich temat. Ponieważ w zdecydowanej większości szpitali nie prowadzono ewidencji mieszkańców, najczęściej pozostawali

152 Tamże, k. 520v.

153 Tamże, k. 538v.

154 Tamże, k. 338v.

155 Tamże, k. 381v.

156 Tamże, k. 319v.

157 Tamże, k. 414v.

158 Tamże, k. $544 \mathrm{v}$.

159 Tamże, k. 483.

160 Tamże, k. 522.

161 Tamże, k. 583.

162 Tamże, k. 427.

163 Tamże, k. 560v.

${ }_{164}$ Tamże, k. 265v.

165 Tamże, k. 286v.

166 Tamże, k. 307.

167 Tamże, k. $424 \mathrm{v}$.

168 Tamże, k. 549.

${ }^{169}$ W. Kowalski, Opieka szpitalna i dobroczynność na terenie archidiakonatu sandomierskiego w dobie przedrozbiorowej, [w:] U. Augustyniak, A. Karpiński (red.), Charitas. Miłosierdzie i opieka społeczna w ideologii, normach postępowania i praktyce spoteczności wyznaniowych w Rzeczypospolitej XVI-XVIII wieku, Warszawa 1991, s. 182; W. Męczkowski, Prowizorowie w dawnej Polsce: przyczynek do dziejów magistratury naszej, „Przegląd Historyczny” 1907, t. 5, z. 3, s. 388.

${ }^{170}$ LIVA, f. 669 , ap. 2, b. 221, k. 12, 386v, 634, 642. 
oni anonimowi. Próżno też szukać takich danych w raportach wizytacyjnych. Jedynie raporty dotyczące dwóch szpitali zawierają imię i nazwisko pensjonariuszy, wiek i liczbę lat przebywania w placówce. $Z$ tych szczupłych danych wiemy na przykład, że najmłodszym mieszkańcem szpitala w Krokach była kobieta w wieku 26 lat, najstarsza kobieta miała 84 lata. W Kęstajciach najmłodszym pensjonariuszem również była kobieta w wieku 18 lat, najstarszym kobieta w wieku 88 lat. Najdłużej w szpitalu krockim, bo aż od 27 lat, przebywały dwie kobiety. Natomiast najdłuższym stażem szpitalnika w Kęstajciach mógł się poszczycić mężczyzna znajdujący schronienie w tamtejszym szpitalu od 11 lat ${ }^{171}$. Ogólnie rzecz biorąc, pensjonariusze spędzali w szpitalach przeciętnie po kilka, a nawet kilkanaście lat, pozostając w nich aż do śmierci.

Jak już ustaliliśmy, ubodzy szpitalni większość czasu spędzali na zbieraniu jałmużny. $Z$ nielicznych informacji na temat życia wewnętrznego przytułków zawartych w raportach dziekańskich dowiadujemy się jeszcze o innych zajęciach szpitalników. Tam gdzie szpital posiadał ogródki, dodatkowym zajęciem była praca przy ich uprawie. Wydzielone ogródki warzywne uprawiali na przykład ubodzy w Bejsagole i Jurborku ${ }^{172}$. Osoby mające schronienie w szpitalach w Girdyszkach, Korcianach, Masiadach, Taurogach „,pełniły posługę kościołowi”173.

Część dnia wypełniały szpitalnikom także praktyki religijne wynikające z woli fundatora, darczyńców czy też z polecenia proboszczów. Trzech ubogich dzwonników ze szpitala w Krakinowie miało obowiązek codziennego śpiewania różańca świętego za duszę fundatorów ${ }^{174}$. Podobnie do codziennego śpiewania różańca świętego w intencji ofiarodawców były zobowiązane pensjonariuszki ze szpitala dla kobiet w Sałantach $^{175}$. Ubodzy ze szpitali w Lalach, Szydłowie i Żoginiach ,pilnowali nabożeństwa wedle przepisu plebana" ${ }^{176}$, podobnie jak ubodzy ze szpitala w Cytowianach, którzy pilnowali „nabożeństwa uporządkowaniem zwierzchnika naznaczonego" ${ }^{177}$. Kobiety przebywające w szpitalu w Chwałojniach, nazywanym „domkiem dewot”, codziennie przed pierwszą mszą odmawiały koronkę za duszę fundatora. Poza tym dbały o czystość bielizny kościelnej i utrzymanie porządku w kościele ${ }^{178}$.

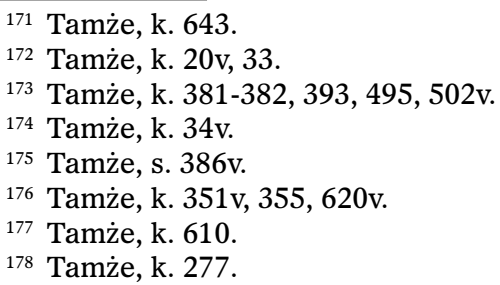




\section{Zakończenie}

W podsumowaniu należy stwierdzić, że szpitale w diecezji żmudzkiej na początku XIX stulecia nie odbiegały zasadniczo od szpitali z innych terenów Rzeczypospolitej Obojga Narodów. Trzeba także podkreślić, że na Żmudzi procentowy wskaźnik parafii ze szpitalem zdecydowanie przewyższał średnie wartości w pozostałych diecezjach polskich omawianego okresu. Oscylował na wysokim poziomie $92 \%$. Biskupstwo ze stolicą we Wroniach górowało także nad diecezjami wschodnimi z ziem litewskich i ruskich, jeśli chodzi o gęstości sieci parafialnej. Pod tym względem wypadało mniej korzystnie - co zrozumiałe, biorąc pod uwagę rozległość terytorium - na tle biskupstw w Koronie, wyprzedzając jednak diecezję włocławską. Ogólnie rzecz ujmując, większość szpitali-przytułków nie posiadała funduszy, a podstawą ich utrzymania była jałmużna. Tylko $\mathrm{w}$ minimalnym stopniu zaspokajały one potrzeby ludzi ubogich i chorych, zapewniając im jedynie dach nad głową. Materialne podstawy działalności szpitali wpływały w decydujący sposób na wygląd architektoniczny budynków szpitalnych, liczbę miejsc, warunki mieszkaniowe, a także determinowały codzienne obowiązki, zajęcia oraz zwyczaje pensjonariuszy. Uwarunkowania te na gruncie żmudzkim nie różniły się od pozostałych ziem Rzeczypospolitej schyłku XVIII w. Jak wykazały badania, proces powolnego zanikania szpitali-przytułków pod koniec XVIII i w początkach XIX w. nie dotknął diecezji żmudzkiej. Prawie wszystkie szpitale działające $\mathrm{w}$ latach 1805-1806 istniały także w latach 20. XIX stulecia. Proces reformy szpitalnictwa w nowym duchu na Żmudzi rozpoczął się później. Problem ten wymaga jednak odrębnego opracowania. 
Marek Hałaburda

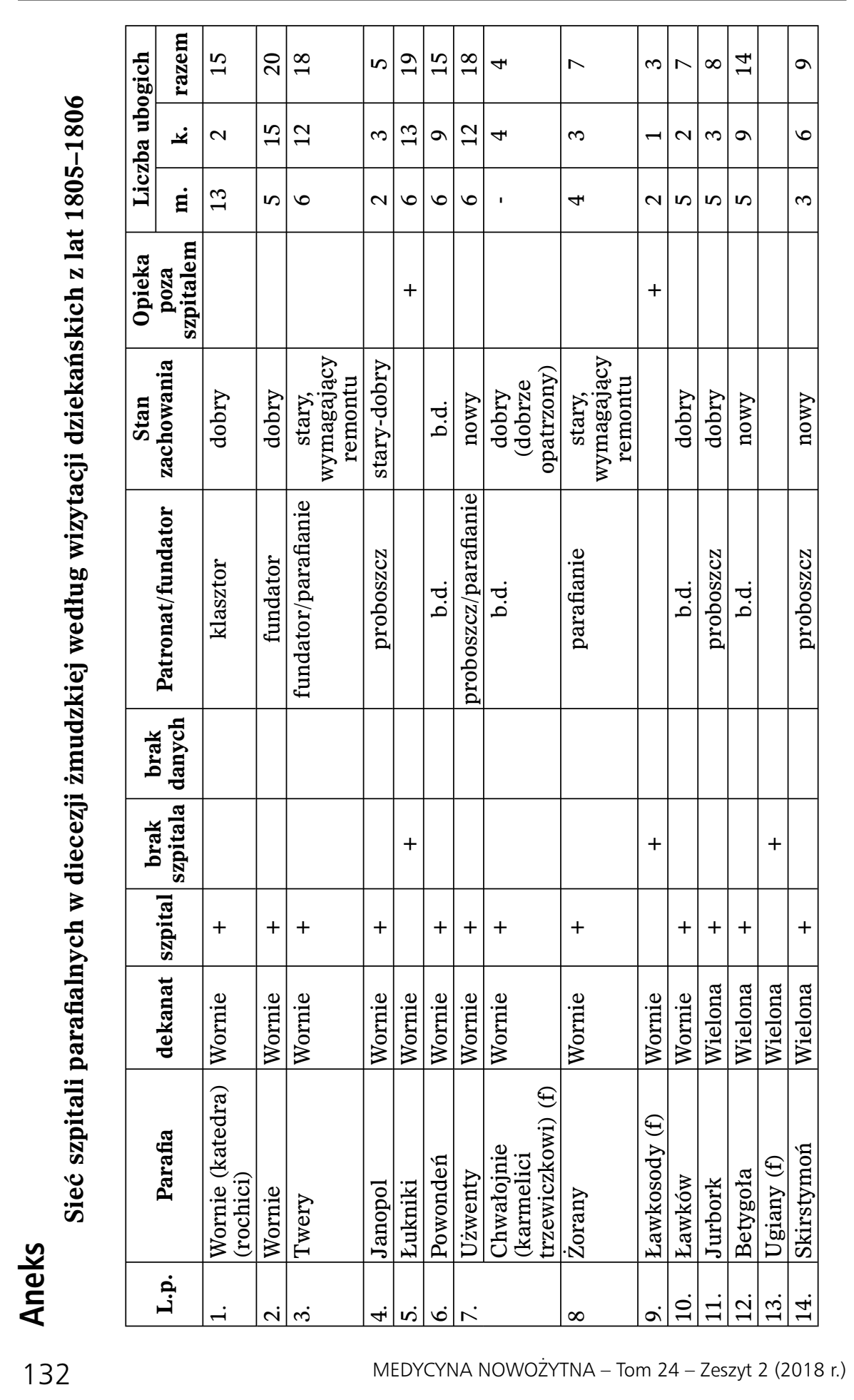


Szpitale diecezji żmudzkiej na początku XIX stulecia

\begin{tabular}{|c|c|c|c|c|c|c|c|c|c|c|c|c|c|c|c|}
\hline$\infty$ & in & $a$ & $\Lambda$ & $\Lambda$ & 0 & 의 & $\underset{\sim}{\sim}$ & & & $\underset{-}{\sim}$ & & $\underset{-}{\sim}$ & - & $\Lambda$ & 6 \\
\hline+ & +4 & $\Lambda$ & $\wedge$ & $\infty$ & $\sigma$ & $\wedge$ & r & & & is & & $\wedge$ & - & $\sim$ & $m$ \\
\hline$F$ & -1 & $N$ & ' & $\sigma$ & $v$ & ח & $\infty$ & & & $\wedge$ & & in & ' & is & $\infty$ \\
\hline 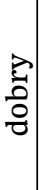 & 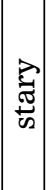 & $\begin{array}{l}3 \\
0 \\
\vdots\end{array}$ & 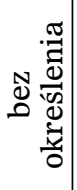 & 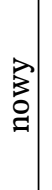 & $\begin{array}{l}3 \\
0 \\
\vdots \\
2\end{array}$ & $\begin{array}{l}3 \\
0 \\
0\end{array}$ & 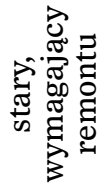 & & & 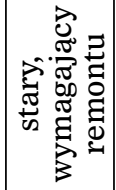 & & 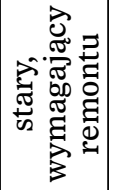 & 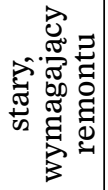 & 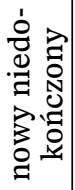 & 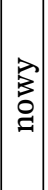 \\
\hline فذّ & 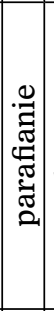 & $\begin{array}{l} \\
\\
N \\
N \\
0 \\
0 \\
0 \\
0 \\
\vdots \\
\vdots \\
\end{array}$ & 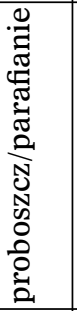 & 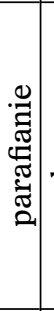 & 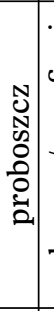 & 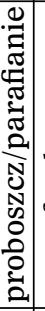 & 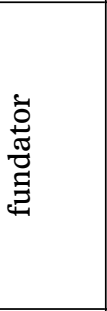 & & & 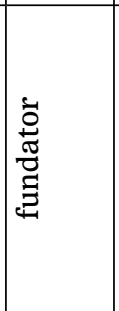 & & $\begin{array}{l}\text { N } \\
N \\
0 \\
0 \\
0 \\
0 \\
0\end{array}$ & 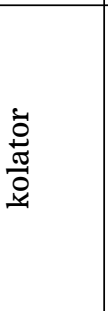 & فُه & فنذّ \\
\hline & & & & & & & & + & + & & & & & & \\
\hline+ & + & + & + & + & + & + & + & & & + & & + & + & + & + \\
\hline 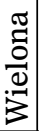 & 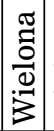 & 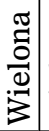 & $\begin{array}{l}\stackrel{0}{0} \\
\stackrel{0}{0} \\
\stackrel{3}{3}\end{array}$ & 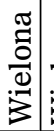 & 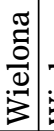 & 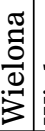 & $\frac{\widetilde{\Xi}}{\stackrel{\Xi}{0}}$ & 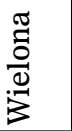 & 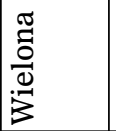 & 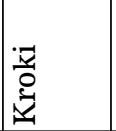 & & 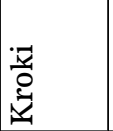 & 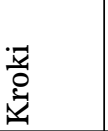 & 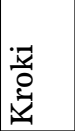 & 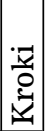 \\
\hline 胥 & 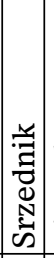 & 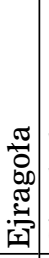 & 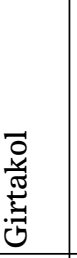 & 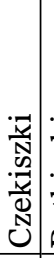 & 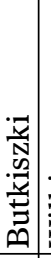 & 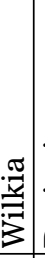 & 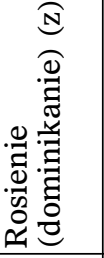 & 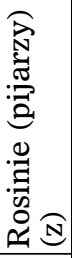 & 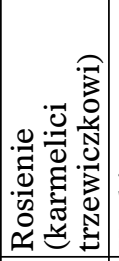 & | & 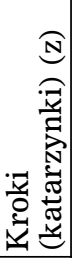 & . & 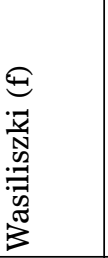 & 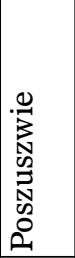 & 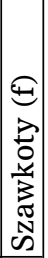 \\
\hline in & $\mid \begin{array}{l}0 \\
-1\end{array}$ & 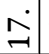 & $\infty$ & 2 & 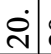 & $\stackrel{\sim}{\circ}$ & $\vec{\sim}$ & 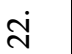 & $\stackrel{\sim}{\sim}$ & $\stackrel{\sim}{\sim}$ & $\stackrel{\sim}{\sim}$ & $\stackrel{\sim}{\sim}$ & $\widehat{\triangle}$ & $\stackrel{\infty}{\sim}$ & নิ \\
\hline
\end{tabular}


Marek Hałaburda

\begin{tabular}{|c|c|c|c|c|c|c|c|c|c|c|c|c|c|}
\hline 6 & $\sim$ & $\wedge \quad 0$ & $n$ & $n$ & N & in & $\bar{N}$ & $\stackrel{\leftrightarrow}{\rightarrow}$ & 이 & & & & 0 \\
\hline$\infty$ & -1 & $\infty / \infty$ & $\infty$ & H & - & $N$ & $\approx$ & $a$ & 0 & & & & $\infty$ \\
\hline$\infty$ & -1 & $+\infty$ & $H$ & $\infty$ & - & $\infty$ & $r$ & $r$ & $\theta$ & & & & $\infty$ \\
\hline+ & & + & & & & & & & & & & & \\
\hline & 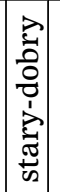 & & 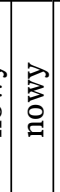 & 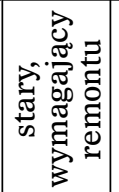 & 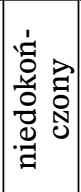 & 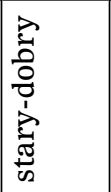 & 訔 & 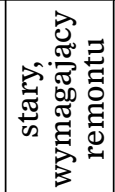 & ? & & & & 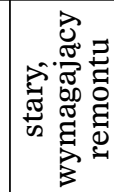 \\
\hline & 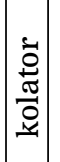 & & 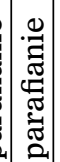 & نُ & 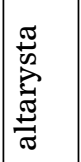 & 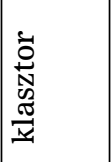 & 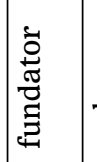 & $\begin{array}{l}\text { N } \\
\text { Un } \\
0 \\
0 \\
0 \\
0\end{array}$ & $\begin{array}{l}N \\
0 \\
0 \\
0 \\
0 \\
0 \\
0\end{array}$ & & & & 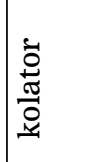 \\
\hline+ & & + & & & & & & & & + & + & + & \\
\hline & + & + & + & + & + & + & + & + & + & & & & + \\
\hline 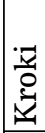 & $\mid$ & 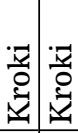 & 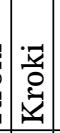 & 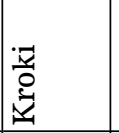 & 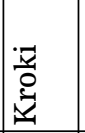 & 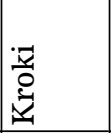 & 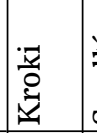 & 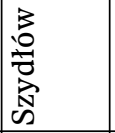 & 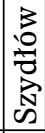 & & & $\mid \begin{array}{l}3 \\
0 \\
0 \\
0 \\
0 \\
0 \\
0\end{array}$ & 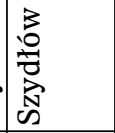 \\
\hline 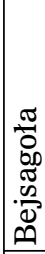 & 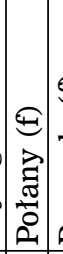 & 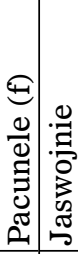 & 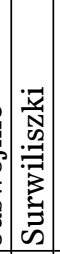 & 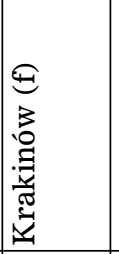 & 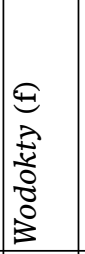 & 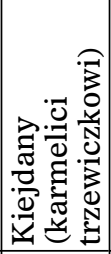 & : & है & 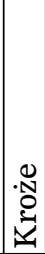 & 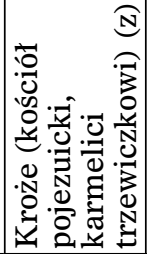 & 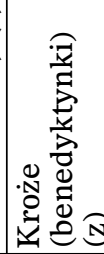 & 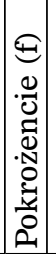 & 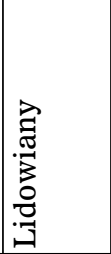 \\
\hline$\dot{m}$ & $|\dot{m}|$ & cి & ले & ம் & ம் & $\hat{\infty}$ & 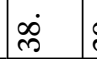 & लें & i & $\dot{\Varangle}$ & $\stackrel{\text { \& }}{\text { f }}$ & $\dot{\mathscr{P}} \mid$ & \&i \\
\hline
\end{tabular}


Szpitale diecezji żmudzkiej na początku XIX stulecia

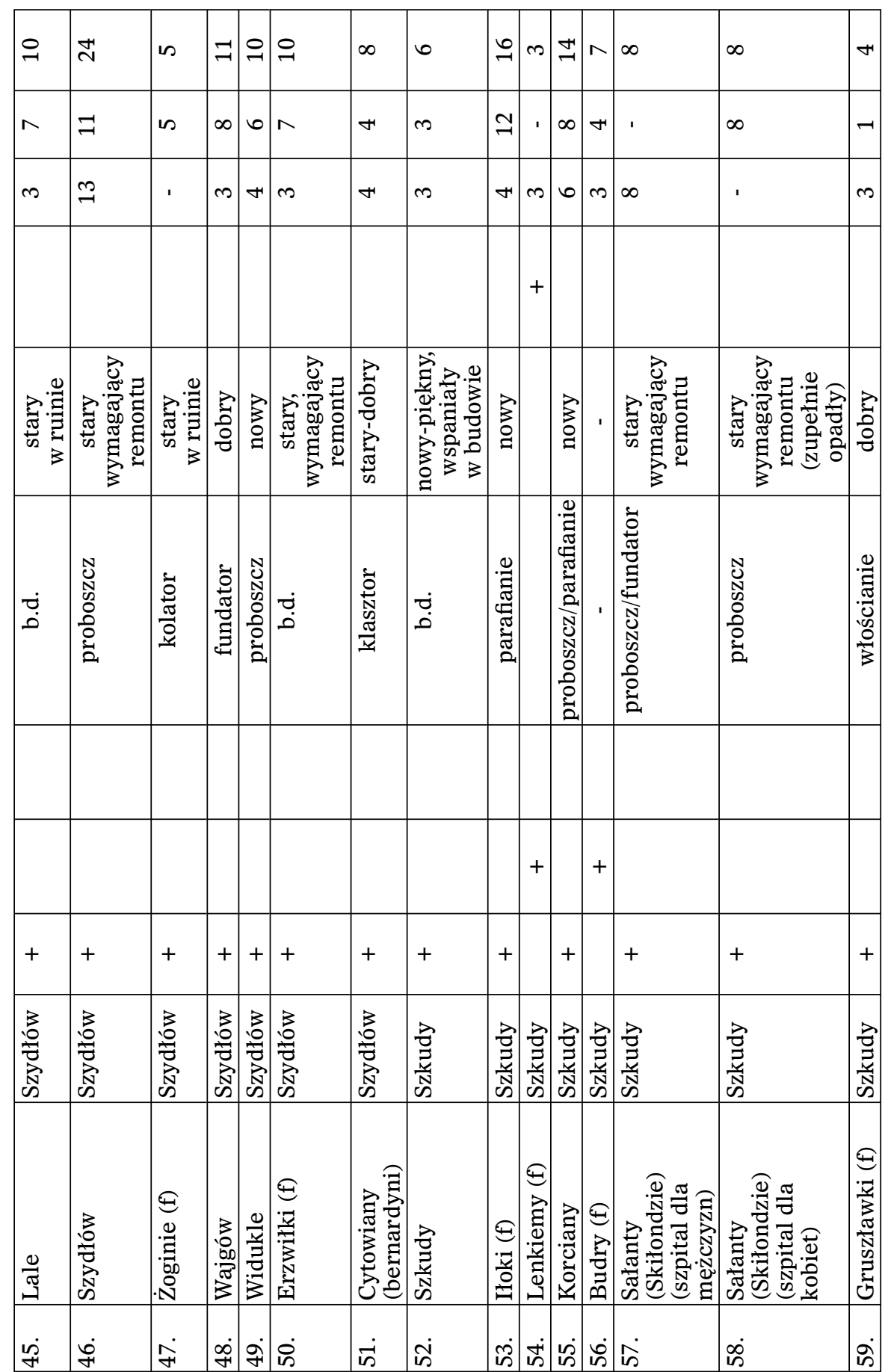


Marek Hałaburda

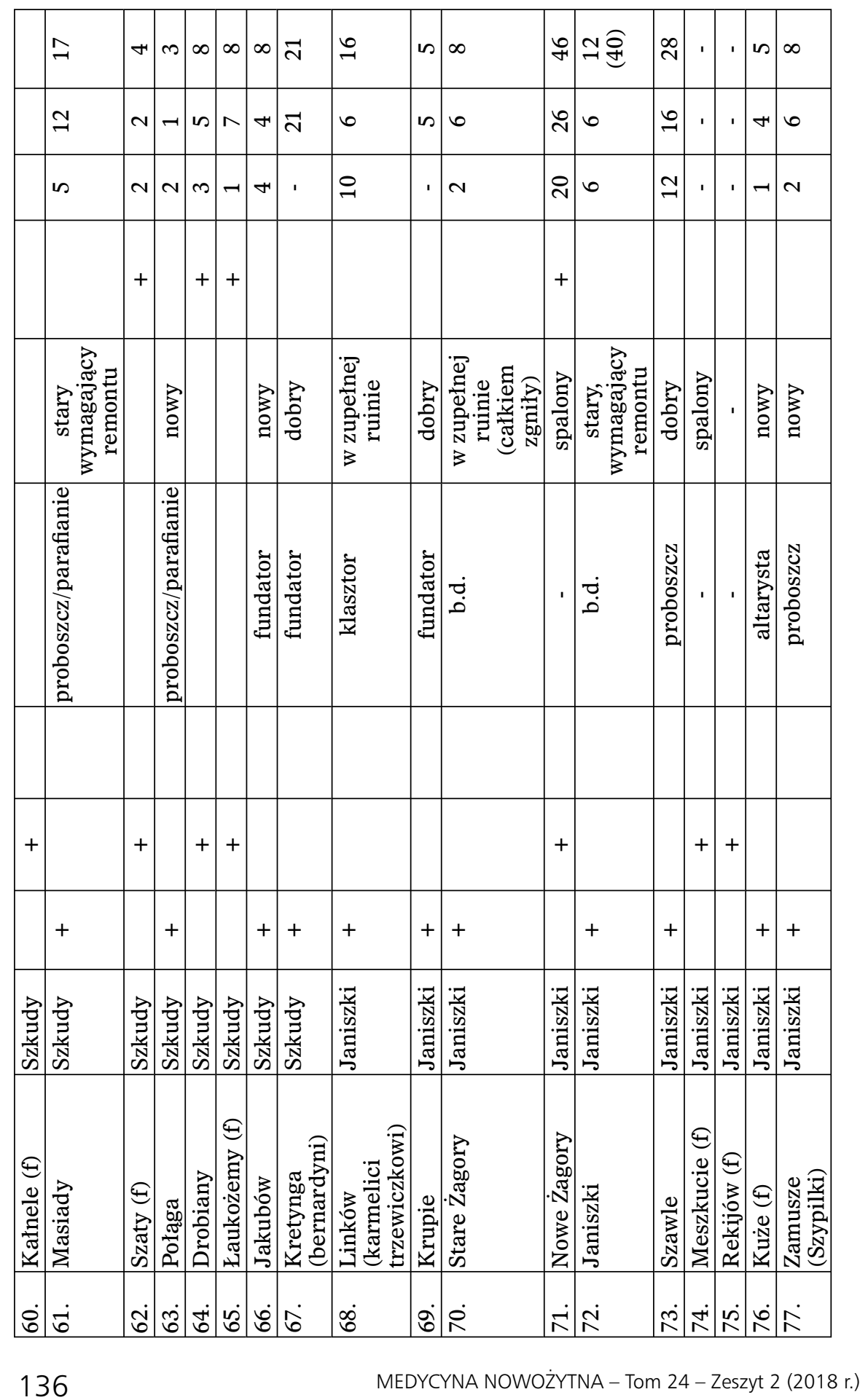


Szpitale diecezji żmudzkiej na początku XIX stulecia

\begin{tabular}{|c|c|c|c|c|c|c|c|c|c|c|c|c|c|c|c|c|}
\hline is & $\stackrel{2}{7}$ & 10 & & & $\stackrel{\sim}{N}$ & & $a$ & $\infty$ & $\underset{-}{\sim}$ & $\widehat{\wedge}$ & 6 & $\ddot{\rightarrow}$ & $\stackrel{\oplus}{\rightarrow}$ & $\stackrel{2}{2}$ & $\stackrel{7}{\sim}$ & $\stackrel{ }{-}$ \\
\hline ' & $\stackrel{10}{\rightarrow}$ & $\infty$ & & & 10 & & $\mid \begin{array}{l}\mid \\
\dot{0}\end{array}$ & $r$ & $\Lambda$ & $\approx$ & $r$ & $\exists$ & $\stackrel{\circ}{-}$ & $\underset{\sim}{\sim}$ & $a$ & $\infty$ \\
\hline in & ' & $\sim$ & & & $\stackrel{0}{-}$ & & $\mid$ & 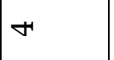 & $n$ & is & $\sim$ & $\sim$ & $n$ & $\Lambda$ & 6 & $\sim$ \\
\hline $\begin{array}{l}\text { 륨 } \\
\text { 음 }\end{array}$ & 客 & 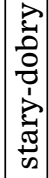 & & & 完 & & $\left|\begin{array}{c}0 \\
3 \\
0 \\
0 \\
0 \\
3 \\
3 \\
3\end{array}\right|$ & 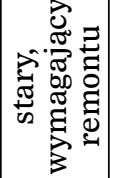 & 吢 & $\begin{array}{l}0 \\
0 \\
0 \\
0\end{array}$ & 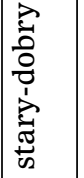 & $\begin{array}{l}\text { 램 } \\
\text { 음 }\end{array}$ & 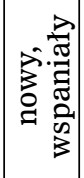 & 룽 & 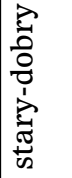 & 客 \\
\hline 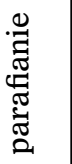 & $\begin{array}{l}\text { N } \\
N \\
0 \\
0 \\
0 \\
0 \\
0 \\
0\end{array}$ & $\begin{array}{l}N \\
\mathcal{N} \\
0 \\
0 \\
0 \\
0 \\
0 \\
\vdots \\
\vdots\end{array}$ & & & $\begin{array}{l}N \\
\mathcal{N} \\
0 \\
0 \\
0 \\
0 \\
0 \\
\vdots\end{array}$ & & فْذَ & 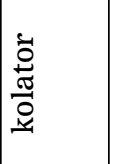 & 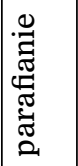 & $\begin{array}{l}\text { N } \\
\text { N } \\
0 \\
0 \\
0 \\
0 \\
0 \\
0\end{array}$ & 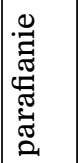 & 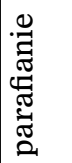 & $\begin{array}{l}\text { N } \\
\text { N } \\
0 \\
0 \\
0 \\
0 \\
0 \\
0\end{array}$ & 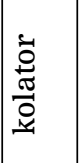 & 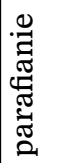 & $\begin{array}{l}\text { N } \\
\text { N } \\
0 \\
0 \\
0 \\
0 \\
0 \\
0\end{array}$ \\
\hline & & & + & + & & + & & & & & & & & & & \\
\hline+ & + & + & & & + & & + & + & + & + & + & + & + & + & + & + \\
\hline 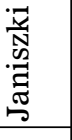 & 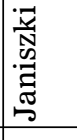 & 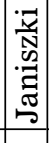 & 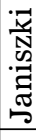 & 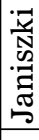 & 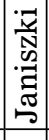 & 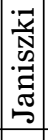 & 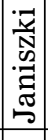 & 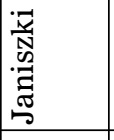 & 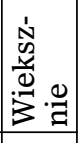 & 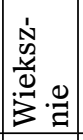 & 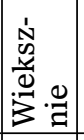 & 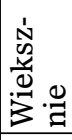 & 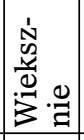 & 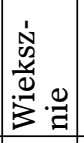 & 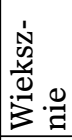 & 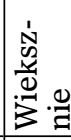 \\
\hline 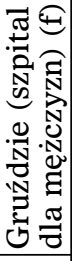 & 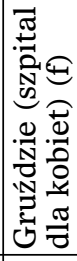 & 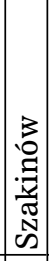 & 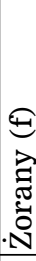 & 苂 & 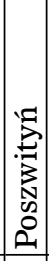 & 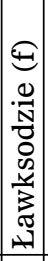 & $\mid$ & 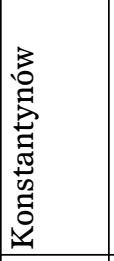 & 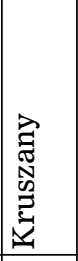 & 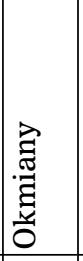 & 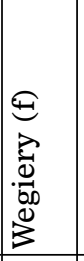 & 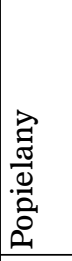 & 岕 & 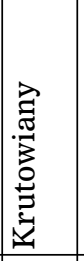 & 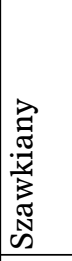 & 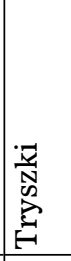 \\
\hline$\stackrel{\infty}{\wedge}$ & 2 & $\dot{\infty}$ & $\dot{\infty}$ & $\infty$ & $\dot{\infty}$ & ஓं & $|\dot{\infty}|$ & $\dot{\infty}$ & $\dot{\infty}$ & $\begin{array}{l}\infty \\
\infty\end{array}$ & $\infty$ & வ் & बं & ส่ & $\ddot{\alpha}$ & જં \\
\hline
\end{tabular}


Marek Hałaburda

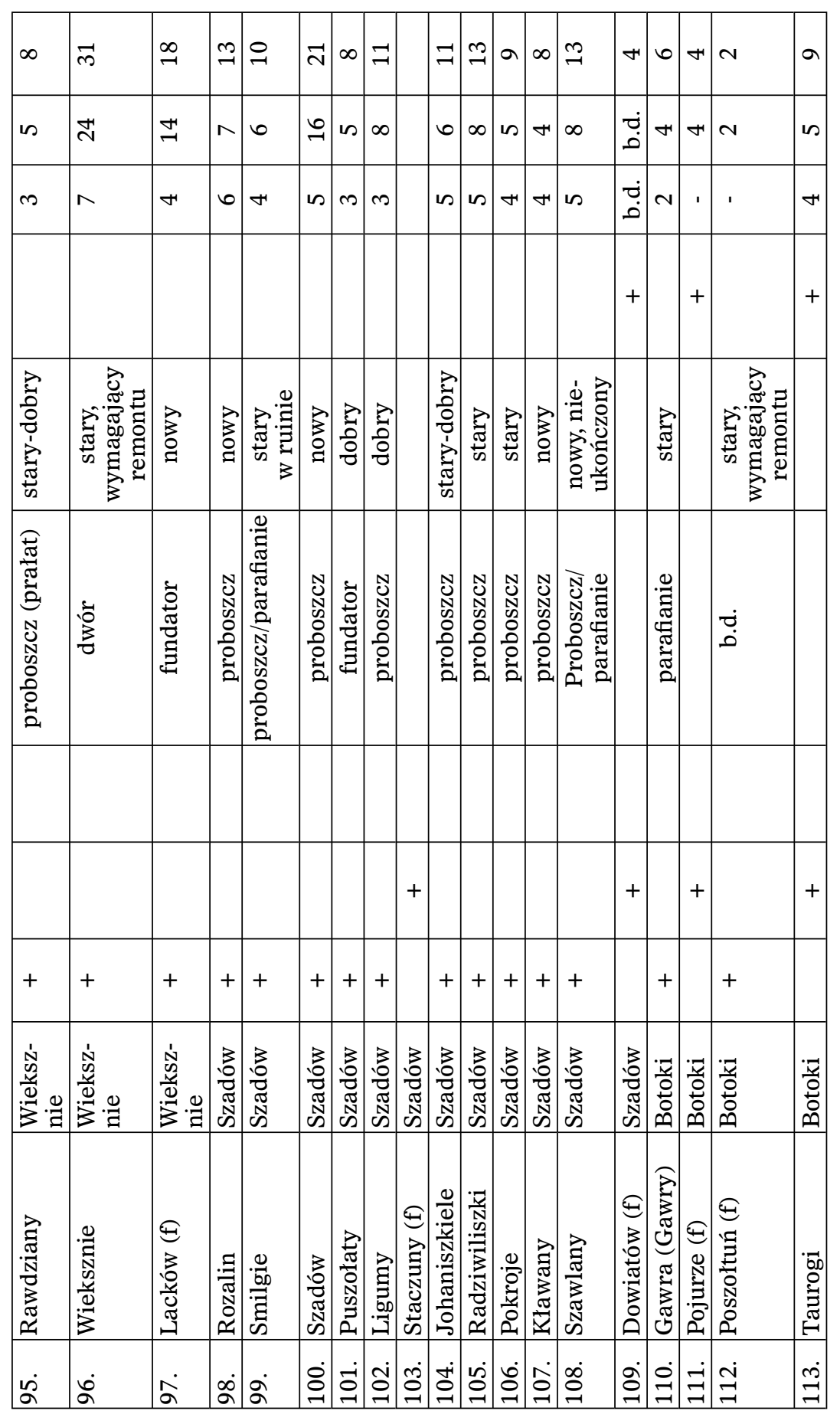


Szpitale diecezji żmudzkiej na początku XIX stulecia

\begin{tabular}{|c|c|c|c|c|c|c|c|c|c|c|c|c|c|c|c|c|}
\hline & $\underset{7}{\sim}$ & & $\exists$ & in & in & N & $\approx$ & in & 0 & $\wedge$ & 6 & & 이 & $\Xi$ & & $\sigma$ \\
\hline & $a$ & & 윽 & $m$ & $\infty$ & -1 & $\stackrel{\infty}{-1}$ & $\infty$ & $r$ & in & $m$ & & إ) & 윽 & & $N$ \\
\hline & $m$ & & -1 & $N$ & $N$ & -1 & $\sigma$ & $N$ & $\sim$ & $\sim$ & $m$ & & is & $\sigma$ & & $\sim$ \\
\hline & & & & & + & & & + & & & & & & & & \\
\hline 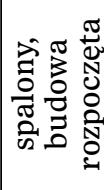 & 焉 & & 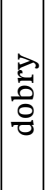 & 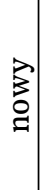 & & 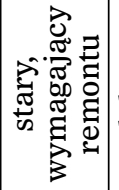 & $\begin{array}{l}2 \\
\text { : } \\
0 \\
0 \\
0\end{array}$ & & 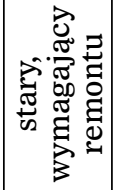 & 恿 & $\begin{array}{l}2 \\
0 \\
0 \\
0 \\
-0\end{array}$ & & 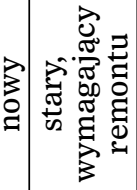 & : & & 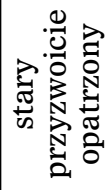 \\
\hline & 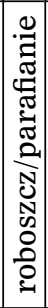 & & $\begin{array}{l}\mathrm{N} \\
N \\
0 \\
0 \\
0 \\
0 \\
0 \\
0\end{array}$ & $\begin{array}{l}\tilde{0} \\
\stackrel{\vec{t}}{0} \\
\underline{0}\end{array}$ & & 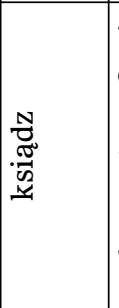 & 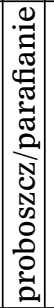 & & 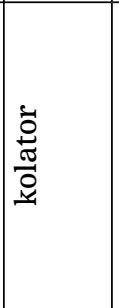 & 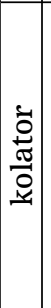 & 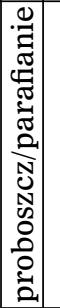 & & 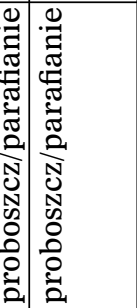 & 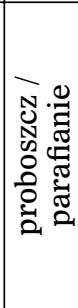 & & 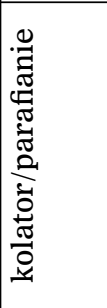 \\
\hline+ & & + & & & + & & & + & & & & + & & & + & \\
\hline & + & & + & + & & + & + & & + & + & + & & ++ & + & & + \\
\hline $\begin{array}{l}\text { 종 } \\
\text { 옹 } \\
0\end{array}$ & 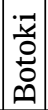 & 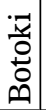 & $\mid$\begin{tabular}{|c|}
$\vec{y}$ \\
0 \\
0 \\
0 \\
0 \\
0
\end{tabular} & 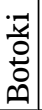 & 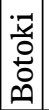 & 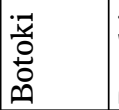 & 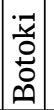 & 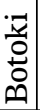 & 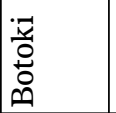 & $\mid$ & $\mid$ & 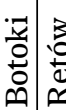 & 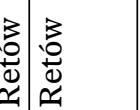 & 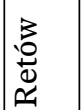 & $\left|\begin{array}{c}3 \\
0 \\
0 \\
0 \\
0 \\
\end{array}\right|$ & 容 \\
\hline 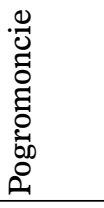 & $\begin{array}{l}\frac{\omega}{\omega} \\
\underset{\sim}{*}\end{array}$ & 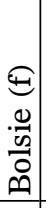 & 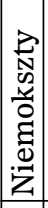 & 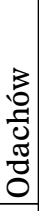 & 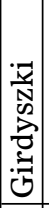 & 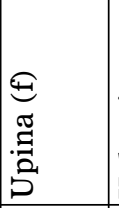 & 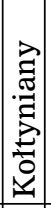 & 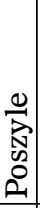 & 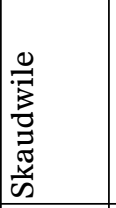 & $\mid$ & 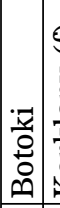 & 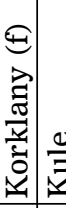 & 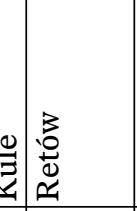 & 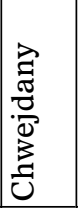 & 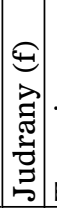 & 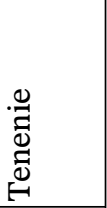 \\
\hline$\stackrel{+}{\exists}$ & in & $\begin{array}{l}\dot{0} \\
\stackrel{\sigma}{\sigma}\end{array}$ & 금 & $\stackrel{\infty}{=}$ & $\stackrel{0}{\exists}$ & $\stackrel{\text { ㄱ }}{\sim}$ & $\dot{-i}$ & ิㅡㄱ & $\stackrel{\overbrace{}}{\sim}$ & $\underset{\exists}{\stackrel{i}{-}}$ & 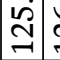 & 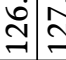 & 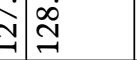 & ิㅗㅇ & 官 & ஜ் \\
\hline
\end{tabular}


Marek Hałaburda

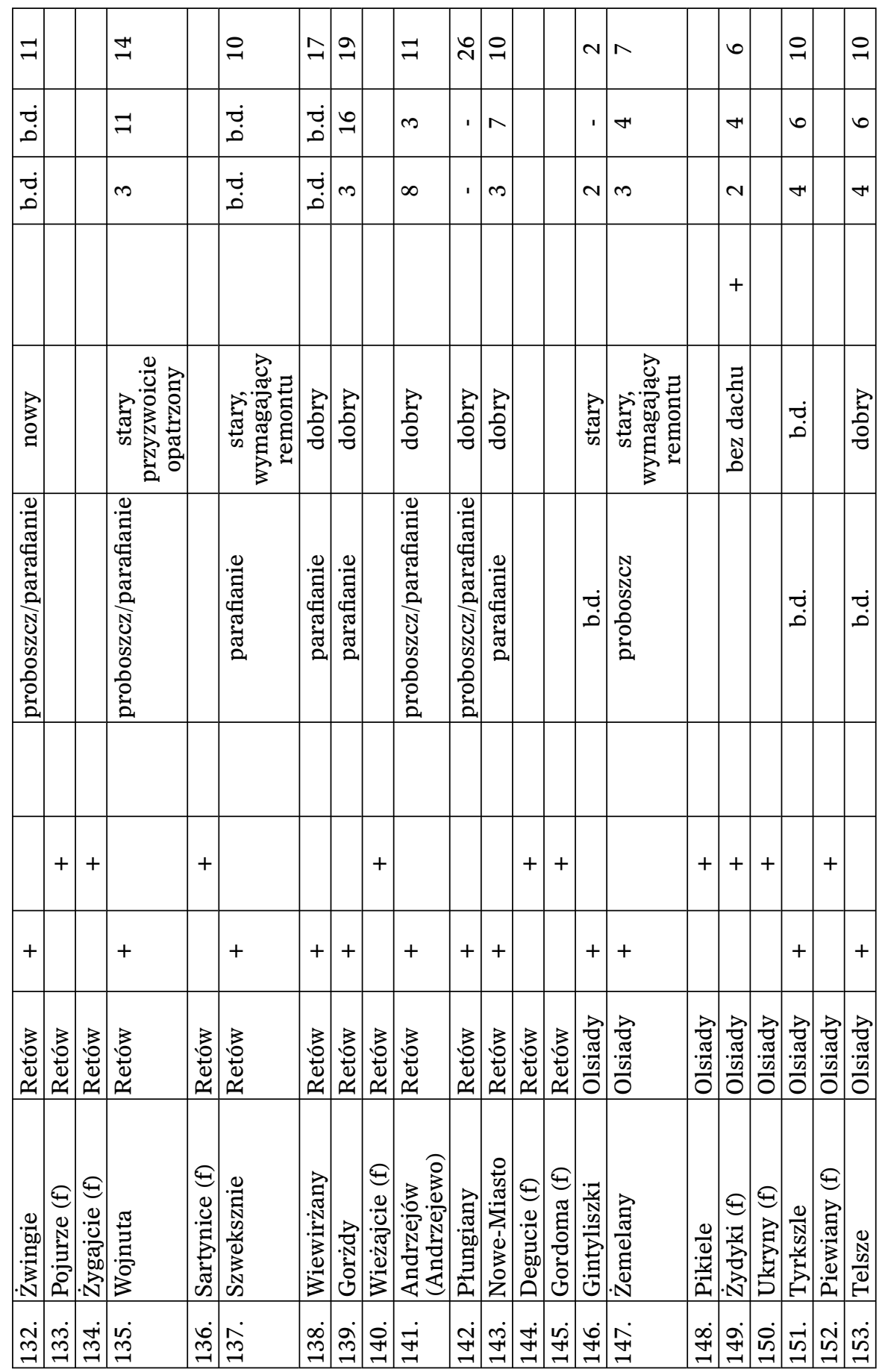


Szpitale diecezji żmudzkiej na początku XIX stulecia

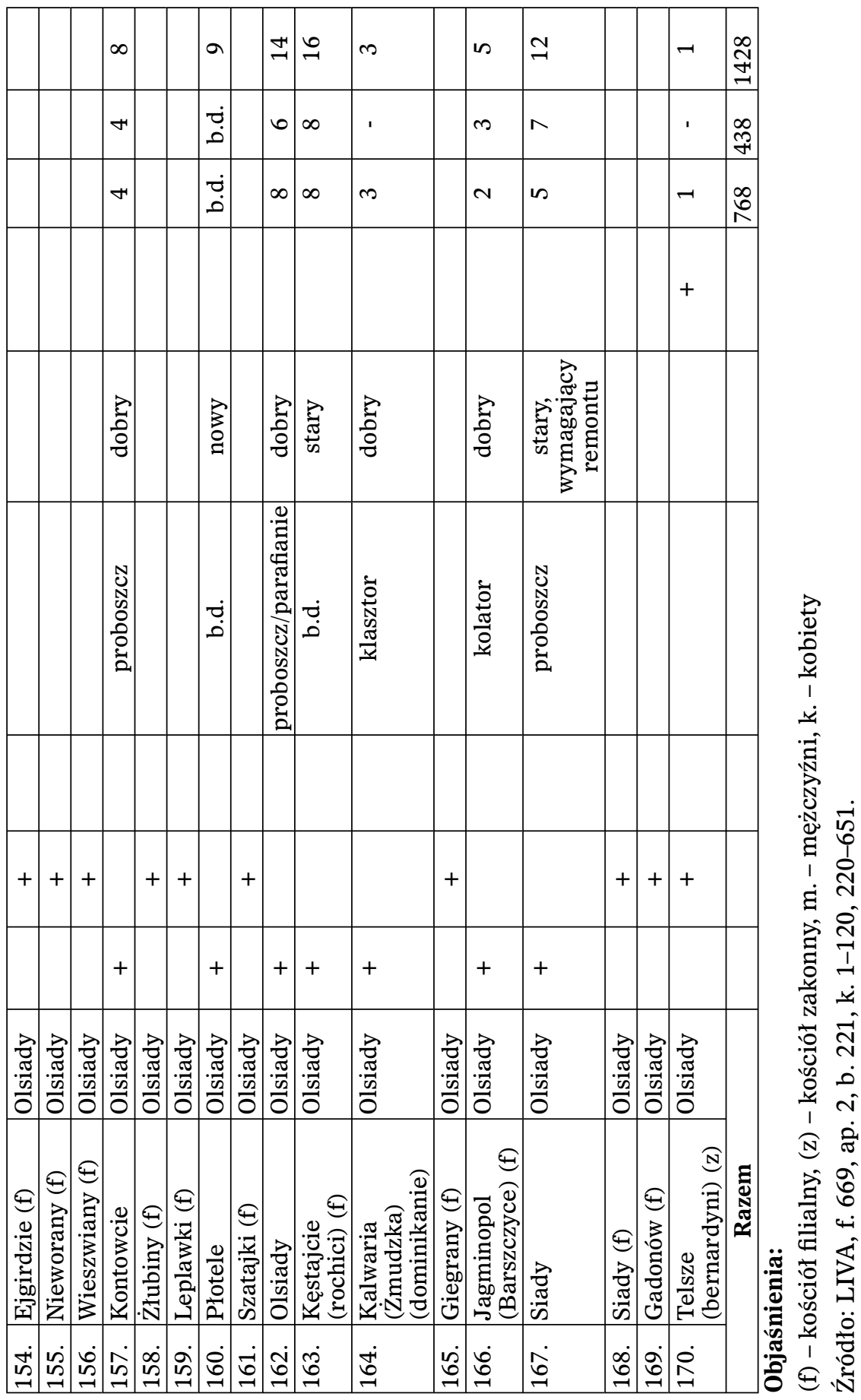




\section{Bibliografia}

\section{Źródła archiwalne}

Litewskie Państwowe Archiwum Historyczne w Wilnie (Lietuvos Centrinis Valstybès Archyvas) (LIVA)

f. 669, ap. 2, b. 221 [Akta wizytacji kościołów diecezji żmudzkiej, $1805 / 1806]$

f. 669, ap. 2, b. 225 Акты визитации костёлов, монастырей и часовен по деканатам Тельшевской епархии, 1821 г.

f. 669 , ap. 2, b. $226 \quad 1821 \mathrm{~m}$. vizitaciju aktai.

f. 669, ap. 2, b. 227 [Wizyty Kościołów Dyecezyi Żmudzkiey, 1821 r.]

f. 669, ap. 2, b. 678 Processa Diecezalne z lat 1796-1805.

\section{Źródła drukowane}

Czerski S., Opis Żmudzkiey Dyecezyi, Wilno 1850.

Kurczewski J., Biskupstwo wileńskie od jego założenia aż do dni obecnych, zawierajace dzieje i prace biskupów i duchowieństwa diecezji wileńskiej oraz wykaz kościołów, klasztorów, szkót i zakładów dobroczynnych $i$ społecznych, Wilno 1912.

Rys historyczno-statystyczny szpitali i innych zakładów dobroczynnych w Królestwie Polskim, t. 1, Warszawa 1872.

Stan szpitalow parafialnych czyli gosod dla ubogich $w$ dyecezyi żmudzkiey podtug wizyty jeneralnej przez samego biskupa Xiażęcia Józefa Giedroycia w roku 1821 odprawioney, „Dzieje Dobroczynności Krajowey i zagraniczney z wiadomościami ku wydoskonaleniu jey służącemi” 1822, t. 3, kol. 752-769.

Urzadzenie szpitalow parafijalnych $w$ dyecezyi żmudzkiej, „Dzieje Dobroczynności Krajowej i Zagranicznej z Wiadomościami Wydoskonaleniu Jey Służącemi” 1820, t. 1.

Wołonczewski M., Biskupstwo żmujdzkie, Kraków 1898.

\section{Opracowania}

Augustajtys F., Szpitale w Polsce, [w:] Z. Chełmicki (red.), Podręczna encyklopedia kościelna, t. 39-40, Poznań-Warszawa 1914.

Błaszczyk G., Diecezja żmudzka od XV do poczatku XVII wieku, Poznań 1993.

Błażewicz K., Szpitale diecezji płockiej w XVIII wieku, „Notatki Płockie" 2007, t. 47, nr 2/191. 
Budzyński Z., Dzieje opieki społecznej w ziemi przemyskiej i sanockiej (XV-XVIII w.), Przemyśl-Kraków 1987.

Dola K., Opieka społeczna Kościoła, [w:] B. Kumor, Z. Obertyński (red.), Historia Kościoła w Polsce, t. 2, cz. 1, Poznań-Warszawa 1979.

Dola K., Opieka społeczna Kościoła, [w:] B. Kumor, Z. Obertyński (red.), Historia Kościoła w Polsce, t. 2 (1764-1945), cz. 1 (17641918), Poznań-Warszawa 1979.

Dola K, Opieka społeczna Kościoła, [w:] B. Kumor, Z. Obertyński (red.), Historia Kościoła w Polsce, t. 1, cz. 1, Poznań-Warszawa 1974.

Godlewski M., Giedroyć Józef Arnolf, [w:] Polski Słownik Biograficzny, t. 7, Kraków 1948-1958.

Góralski Z., Szpitale na Lubelszczyźnie w okresie przedrozbiorowym, Warszawa-Łódź 1982.

Kamuntavičienè V., Szpitale i szkoły parafialne diecezji wileńskiej $i$ żmudzkiej w drugiej połowie XVII wieku wedtug danych akt wizytacyjnych Kościoła katolickiego, „Kwartalnik Historyczny” 2003, R. 110, nr 2.

Kopiczko A., Szpitalnictwo na Warmii w XVI-XVIII wieku, [w:] M. Dąbrowska, J. Kruppè (red.), Szpitalnictwo w dawnej Polsce, Warszawa 1998.

Korpalska W. K., Sześć wieków opieki zdrowotnej w Bydgoszczy. Od miłosiernych uczynków do instytucji zdrowia publicznego, Toruń 2008.

Kowalski W., Opieka szpitalna i dobroczynność na terenie archidiakonatu sandomierskiego $w$ dobie przedrozbiorowej, [w:] U. Augustyniak, A. Karpiński (red.), Charitas. Miłosierdzie i opieka społeczna w ideologii, normach postępowania i praktyce społeczności wyznaniowych w Rzeczypospolitej XVI-XVIII wieku, Warszawa 1991.

Krętosz J., Organizacja archidiecezji lwowskiej obrządku łacińskiego od XV wieku do 1772 roku, Lublin 1986.

Królik L., Organizacja diecezji tuckiej i brzeskiej od XVI do XVIII wie$k u$, Lublin 1983.

Królik L., Szpital św. Ducha w Warszawie od XV do XVIII wieku, zarys dziejów, „Studia Theologica Varsaviensia” 1984, t. 22, nr 2.

Kumor B., Granice metropolii i diecezji polskich (968-1939), „ABMK” 1970, t. 20. 
Kumor B., Ustrój i organizacja Kościoła polskiego w okresie niewoli narodowej (1772-1918), Kraków 1980.

Litak S., Atlas Kościoła łacińskiego w Rzeczypospolitej Obojga Narodów w XVIII wieku, Lublin 2006.

Litak S., Parafie w Rzeczypospolitej w XVI-XVIII wieku, Lublin 2004.

Męczkowski W., Prowizorowie w dawnej Polsce: przyczynek do dziejów magistratury naszej, „Przegląd Historyczny” 1907, t. 5, z. 3.

Partyka W., Szpitale w diecezji wileńskiej w drugiej połowie XVIII wie$k u$, [w:] M. Surdacki (red.), Religia - Edukacja - Kultura, Lublin 2002.

Podgórska-Klawe Z., Od hospicjum do wspótczesnego szpitala. Rozwój historyczny problematyki szpitalnej w Polsce do końca XIX wieku, Wrocław-Warszawa-Kraków 1981.

Prašmantaitė A., Žemaičiu vyskupas Juozapas Arnulfas Giedraitis, Vilnius 2000.

Prašmantaitė A., Żmudzki biskup Józef Arnulf Giedroyć (1757-1838) i jego diecezja, Poznań 2001.

Skarbek J., Kościół rzymskokatolicki na Białorusi i Litwie w XIX i na poczatkach XX stulecia, „Sympozjum” 1999, R. 3, nr 1(4).

Surdacki M., Opieka społeczna w Polsce do końca XVIII wieku, Lublin 2015.

Surdacki M., Opieka społeczna w Wielkopolsce Zachodniej w XVII i XVIII wieku, Lublin 1992.

Surdacki M., Protestanci a rozwój szpitali w Wielkopolsce Zachodniej w XVII o XVIII wieku, „Odrodzenia i reformacja w Polsce” 1991, t. 36 .

Surdacki M., Szpital Świętego Ducha i Św. Leonarda w Urzędowie w XV-XVIII wieku, „Kwartalnik Historyczny” 2004, R. 62, z. 2.

Wachholz L., Szpitale krakowskie 1220-1920, cz. 2, Kraków 1924.

Woźniak A., Szpitale wiejskie na Mazowszu w końcu XVIII wieku i poczattku XIZX wieku, [w:] M. Dąbrowska, J. Kruppè (red.), Szpitalnictwo w dawnej Polsce, Warszawa 1998.

Zahorski W., Pierwsze szpitale wileńskie (Kartka z historji Szpitalnictwa w Wilnie), „Pamiętnik Wileńskiego Towarzystwa Lekarskiego” 1925, R. 1, z. 1. 


\section{Summary}

\section{Hospitals of the diocese of Żmudź at the beginning of the XIXth century}

The aim of this article is to present a problem of social welfare in the diocese of Żmudź at the beginning of the XIXth century. In the article a source - as a fundamental material needed to write this publication, the condition of the diocese of Żmudź on the turn of the XVIIIth and XIXth centuries, the condition of hospital management on Polish and Lithuanian lands on the turn of the centuries will be presented. In the article a system of hospitals of the diocese of Żmudź, allowance and funds of hospitals, hospital buildings, and finally the poor without which the hospitals would not have existed will also be presented. By Żmudź hospitals we understand all hospital shelters which worked at parish, branch - and monastic churches at that time. The appendix which presents a system of parish hospitals in the diocese of Żmudź based on dean inspections coming from 1805-1806 is a supplement to the whole article. 